\title{
INDEKS MENTAL-KOGNITIF ISLAM: SATU PENANDA ARAS PSIKOSPIRTUAL ISLAM REMAJ A BERISIKO
}

\author{
Khairil Anwar \\ E-mail :karkun74@gmail.com \\ Universitas Islam Negeri Sultan SyarifKasimRiau
}

\begin{abstract}
The purpose of this study was to describe the Islamic Mentalcognitive index on risk youth. Islamic Mental-cognitive termed a structure depths of human childbirth perception, introspection, memory, creativity, imagination, conception, belief, reasoning, volition, and emotions as a unified way of thinking based on Islam, is an attempt to predict and as approaches to identify the problem and solve psychological risk youth. Six recovery centers have been chosen for this study, involving busy as 490 coaches and 128 students of a secondary school of nationality as a collection of the convoy. Background to the economic status of parents of respondents also identified and data collection is done using inquired about the accreditation forms which contains a measurement of Islamic Mental-cognitive. Data were analyzed using a mathematical formula to form the Islamic Mental-cognitive index that consists of multiple domains. Decision of the study showed an index of Islamic Mental-cognitive is at the stage of a low (score 51.56). The discovery of this study backs up one module coaching intervention and prevention against socio-psychological symptoms teens through the principles of the concept of Islamic Mental-cognitive, Islamic psychosocial and sunnah behavior.
\end{abstract}

Key words : Islamic Mental-cognitive, Islamic psycho-spiritual and risk youth.

\section{PENDAHULUAN}

Kemajuan teknologi tanpa diiringi oleh kecerdasan agama dalam konteks Islam disebut dengan kecerdasan tauhid (Tauhidic quotiens), akan membawa kerendahan budi dan adab terutama dalam kalangan remaja. Seperti kemajuan teknologi media massa, apabila tidak mendapat kawalan dapat membawa ke arah keruntuhan akhlak. Maka dalam tuntutan agama, orang yang bertanggungjawab menanamkan nilai agama tersebut adalah orang tua, masyarakat, pemimpin, dan ulama. Apabila di antara unsur-unsur masyarakat yang dimaksudkan mengabaikan dan tidak peduli pada perilaku dan akhlak remaja, maka dengan sendirinya akan terlahirlah remaja remaja yang bermasalah. (Hamzah Ya'qub 1983).

Dalam konteks Malaysia dan Negara Islam sedang membangun, hal yang sangat membimbangkan adalah masalah pergaulan bebas yang mengheret kepada permasalahan besar iaitu jenayah pembunuhan dan 
Al-Fikra: Jurnal IImiah Keislaman, Vol.14, No.2, Juli - Desember 2015

pembuangan bayi. Pergaulan bebas yang ditandai dengan kebebasan melakukan kontidak seksual dalam kalangan remaja sudah menjadi hal yang biasa dan lumrah. Seperti penyelidikan Khaidzir Hj Ismail (2007) seorang Pakar Kanak-kanak dan Psikologi Remaja, mendapati dari 887 remaja sekitar 13 ke 17 tahun yang dikaji, dijumpai hanya hanya satu orang sahaja yang mengaku tidak pernah mengadakan hubungan seks. Selain hubungan seks haram, murid-murid ini turut mengaku ada terlibat dalam kegiatan dadah, kongsi gelap, pornografi, vandalisma dan ponteng.

Selain itu pembunuhan adalah kes jenayah dunia yang sangat dikhawatirkan saat ini, kerana yang melakukan adalah kanak kanak (baca: remaja), artinya terjadi suatu arus jenayah pembunuhan dalam kalangan kanak kanak. Di Amerika terjadi penembakan oleh kanak sekolah dengan melakukan serangkaian pembantaian yang mengerikan, walaupun usianya masih muda. Peningkatan angka kanak-kanak membunuh telah menjadi tragedi besar kemanusiaan. (Harun Yahya 2002). Dalam laporan Halstead (1992), bahawa remaja yang membunuh di Australia berada pada peringkat ke tiga terbesar melakukan pembunuhan, yakni terjadi 44 kes pembunuhan dalam setiap 100,000 orang penduduk pada tahun 1998-90. Hal ini disebabkan oleh Otidak kanak - kanak telah dipengaruhi oleh program TV dan filem yang dipenuhi dengan kekerasan dalam proporsi yang tidak pernah terjadi sebelumnya. Tayangan pembunuh mendominasi beberapa filem tertentu dan berisiko bagi kanak kanak. (Harun Yahya 2002).

Hal yang mendorong para remaja ke dalam persekitaran gelap dan membuat mereka mudah terlibat dengan kekejaman adalah disebabkan mereka hidup berdampingan dengan orang-orang dewasa yang jauh daripada agama. Orang yang tidak takut pada Allah akan melahirkan generasi keji yang tidak takut pada Allah. Mereka menanamkan dalam diri anak-anak mereka perbuatan keji dan bukannya keimanan, belas kasih, dermawan, kejujuran, kebijaksanaan. (Harun Yahya 2002). Terjadinya kejahatan yang dilakukan oleh kanak-kanak bukanlah suatu keanehan, kerana dalam mayarakat tersebut kanak kanaknya tidak diperkenalkan dengan nilai-nilai Islam dan akhlakul karimah. (Harun Yahya 2002). Maka di dalam ajaran Islam dikatakan bahawa perintah melakukan amar ma'ruf nahi munkar adalah syarat mutlak untuk mencegah kemungkaran dan kemaksiatan (Fuad Amsyari 1995), tujuan penganjuran ini dilaksanakan untuk mengantisipasi gejala salah laku dalam kalangan remaja.

Selain daripada dapatan data statistik di atas, dapatan yang ingin dilihat adalah keadaan psikologi remaja yang telah melakukan salah laku yang dimaksud. Kerana faktor dalaman yang akan menjadi pendorong terjadinya sesebuah tingkahlaku. Maka kajian ini cuba melengkapi kajiankajian salah laku remaja yang sedia ada, yang hanya melihat angka-angka 
Khairil Anwar, Indeks Mental - Kognitif Islam : Satu Penanda Aras Psikospirtual Islam Remaja Berisiko

statistik, kepada suatu kajian untuk mengungkapkan fenomena psikologi remaja yang menyebabkan mereka terjebak dalam perbuatan salah laku.

\section{Mental-kognitif Islam}

Dalam banyak literatur sering menyamakan makna antara mental dan kognitif. Kedua konsep ini selalu dimaksudkan dengan erti berfikir. Penyamaan makna kedua konsep ini tidak diketepikan, kerana memang keduanya merujuk kepada proses manusia berfikir. Lebih jauh apabila kedua konsep ini ditelusuri secara mendalam, maka didapati titik perbezaan untuk menerangkan proses manusia berfikir.

Kognitif secara umum adalah suatu proses yang lebih mengarah kepada proses penemuan suatu maklumat atau pengenalan kembali suatu maklumat. Dalam erti kata lain kognitif adalah suatu proses kemampuan manusia berfikir untuk mengenali dan menenmukan maklumat sama ada yang bersumber daripada dalaman manusia mahupun yang bersumber daripada luaran manusia atau faktor persekitaran. Manakala mental adalah motor penggerak dan abstraksi dari proses kognitif yang menghubungkan pola-pola berfikir dengan alam kesedaran manusia, di mana manusia sedar bahawa sedang terjadi proses berfikir yang pada akhirnya kegiatan mental inilah yang akan menjadi titik utama dalam penyelesaian masalah. Jadi dapat dikatakan bahawa mental kognitif adalah proses kecerdasan seseorang menangani masalah dari input-input luaran dan dalaman manusia.

Sebagai perbandingan dapat dirujuk dari teori Cattel (1963) mengenai organisasi mental, beliau mengklasifikasi kemampuan mental menjadi dua jenis, iaitu intelegensi fluid yang merupakan faktor semula jadi biologikal dan kecerdasan crystallized yang mereflaksikan adanya pengaruh pengalaman, pendidikan, budaya dan kebiasaan dalam diri seseorang individu.

Dari teori Cattel ini berkemungkinan dapat dianalogikan proses mental kognitif adalah berlangsung dari dua jenis kemampuan mental di atas. Ertinya secara semula (fluid) jadi setiap orang telah membawa potensi mental kognitif untuk memproses cara berfikirnya, manakala kualiti mental kognitif bergantung kepada persekitaran (crystallized). Tahap Mental kognitif yang baik akan mempengaruhi cara seseorang individu untuk dapat memahami dan menyelesaikan masalah dengan baik. Seiring dengan ini, Mohammad Saleh (2007) menggambarkan bahawa kemampuan kognitif seseorang yang beramal dengan ikhlas, sangat berpengaruh terhadap pola coping seseorang individu untuk menyelesaikan sesuatu masalah.

Dengan demikian menurut Saifuddin Azwar (1996) intelegensi crystallized dapat dipandang sebagai intipati pengalaman yang terjadi sewaktu intelegensi fluid bercampur dengan apa yang disebut intelegensi budaya. Intellegensi crystallized akan meningkat dalam diri seseorang, seiring dengan bertambahnya pengalaman. Dengan kata lain, tugas tugas 
Al-Fikra: Jurnal IImiah Keislaman, Vol.14, No.2, Juli - Desember 2015

kognitif adalah sebagai keterampilan dan kebiasan yang telah mengkristal akibat pengalaman sebelumnya, seperti banyaknya menguasai kosa kata, pengetahuan, kebiasaan penalaran dan pelbagai hal yang berhubungan dengan semua yang akan meningkatkan intelegensi dimaksudkan.

Pemahaman mental kognitif dari teori Cattel di atas, membawa sebuah implikasi yang positif terhadap mengkristalnya mental kognitif dalam menyelesaikan masalah, disamping memberi pengaruh besar terhadap pengetahuan dan pengalaman keagamaan.

Dengan demikian Mental Kognitif Islam dapat dikatakan sebagai istilah khusus yang digunakan untuk melihat pola-pola dan cara berfikir seseorang individu tentang kualiti pengetahuan, pemahaman dan pengamalan tentang keislaman, atau dapat juga dikatakan mental kognitif Islam adalah cara berfikir umat Islam dalam memandang diri dan persekitarannya.

Oleh itu, dari definisi kognitif dan definisi mental yang di terokai, maka istilah Mental-Kognitif Islam defininya adalah suatu struktur dalaman manusia yang melahirkan persepsi, introspeksi, memori, kreativiti, imaginasi , konsepsi, keyakinan, penalaran, kemauan, dan emosi sebagai suatu kesatuan cara berfikir yang berteraskan Islam.

\section{Metode}

Kajian dijalankan secara tinjauan dengan menggunakan soal selidik sebagai instrumen kajian. Manakala persampelan kajian ini adalah berbentuk purposive random sampling, hal ini dimaksudkan sampel diambil hanya pada cluster umur remaja dan secara rawak diambil untuk dijadikan responden kajian. Responden seramai 490 orang remaja yang berumur dalam lingkungan 13 hingga 22 tahun yang berada dalam pusat pemulihan dan dari latar belakang demografi yang berbeza telah dipilih. Bagi responden kajian yang tidak pandai membaca, enumerator telah membantu membacakan soal selidik dimaksud tanpa menerangkan secara terperinci maksud soal selidik, kerana keterangan yang panjang dari enumerator akan menyebabkan tidak mendapat data sebenar tahap variabel mental-kognitif dan psikososial remaja yang akan diukur. Lokasi kajian ini diambil dari empat negeri iaitu Terengganu, Kelantan, Melaka dan Perak. Pemilihan lokasi ini berdasarkan keperluan untuk mengambil responden lelaki dan perempuan. Maka responden perempuan diambil pada pusat pemulihan Melaka, Terengganu dan Kelantan, manakala responden lelaki diambil pada pusat pemulihan di Perak dan Melaka.

Kajian ini menggunakan satu set soal selidik yang terbahagi kepada bahagian latar belakang responden dan bahagian skala-mental kognitif Islam (Khairil \& Khaidzir 2011).Tahap mental-kognitif Islam remaja diukur dengan menggunakan skala binari iaitu jawapan 'ya' dan 'tidak', dimana jawapan 'ya' diberi nilai 2 dan jawapan 'tidak' diberi nilai 1. Skala ini terdiri dari soalan 
Khairil Anwar, Indeks Mental - Kognitif Islam : Satu Penanda Aras Psikospirtual Islam Remaja Berisiko

positif dan negatif. Apabila soalan negatif dijawab pada pilihan 'ya' maka nilainya menjadi 1 dan sebaliknya bila memberi jawapan tidak akan diberi nilai 2. Skala ini memiliki 174 item terdiri dari 4 sub skala seperti di Jadual 3.5 memperlihatkan domain Tauhid 21 item, hukum Islam 79 item, pengetahuan Islam 51 item dan sejarah Islam 23 item.

Indeks mental-kognitif Islam julat yang tinggi adalah skor 60 ke atas. Manakala julat yang rendah adalah di bawah skor 60 ke bawah. Pilihan jawapan mempunyai dua julat (binary) ya dan tidak. Kenyataanpositif (seperti "keikhlasan dapat menyihatkan badan"). Bagi kenyataan negatif (seperti "tidak mengapa tidak percaya dengan adanya malaikat, yang penting percaya kepada Allah SWT")..

Data dianalisis menggunakan formula matematikal (Samsudin A. Rahim 2006) untuk mendapatkan skor domain mental kognitif Islam :

Skor Indikator : $\quad \sum\left[\underline{\mathrm{M}_{1}}-\underline{\mathrm{Ms}}\right] \times 100$

Skor domain : $\quad \bar{X}=\left[\sum\left[\underline{M_{1}}-\frac{M s}{R}\right] \times 100\right]$

Skor Indeks : $\quad \bar{X}$ indeks $=\frac{\sum \bar{X} \text { domain }}{\mathrm{N} \text { domain }}$

Keterangan :

$\Sigma \quad$ : Jumlah skor Indeks

$M_{1} \quad:$ Min

$M_{s} \quad$ : skor minimum

$\mathrm{R} \quad$ : Range (skor maksimum tolak skor minimum)

100 : Skor tertinggi yang dianggarkan

\section{Hasil Penelitian}

\section{Domain Mental-Kognitif Islam}

Menerusi Jadual 1, menunjukkan Domain yang terdapat di dalam mental-kognitif Islam dan skor yang diperolehi. Skor-skor tersebut ialah tauhid (57.24), hukum Islam (57.71), Pengetahuan Islam (51.02) dan sejarah Islam (40.26). Indeks yang diperolehi untuk mental-kognitif Islam ialah 51.56. 
Al-Fikra: Jurnal IImiah Keislaman, Vol.14 , No.2 , Juli - Desember 2015

Jadual 1 Skor Domain Mental-Kognitif Islam

\begin{tabular}{lc}
\hline Domain Mental-Kognitif Islam & Skor \\
\hline Tauhid & 57.24 \\
Hukum Islam & 57.71 \\
Pengetahuan Islam & 51.02 \\
Sejarah Islam & 40.26 \\
Indeks Mental-Kognitif Islam & 51.56 \\
\hline
\end{tabular}

Rajah 1 memperlihatkan bahawa skor domain mental-kognitif Islam yang paling rendah dicapai adalah sejarah Islam (40.21). Selanjutnya Pengetahuan Islam dan tauhid. Manakala hukum Islam (57.71) menempati skor yang tertinggi.

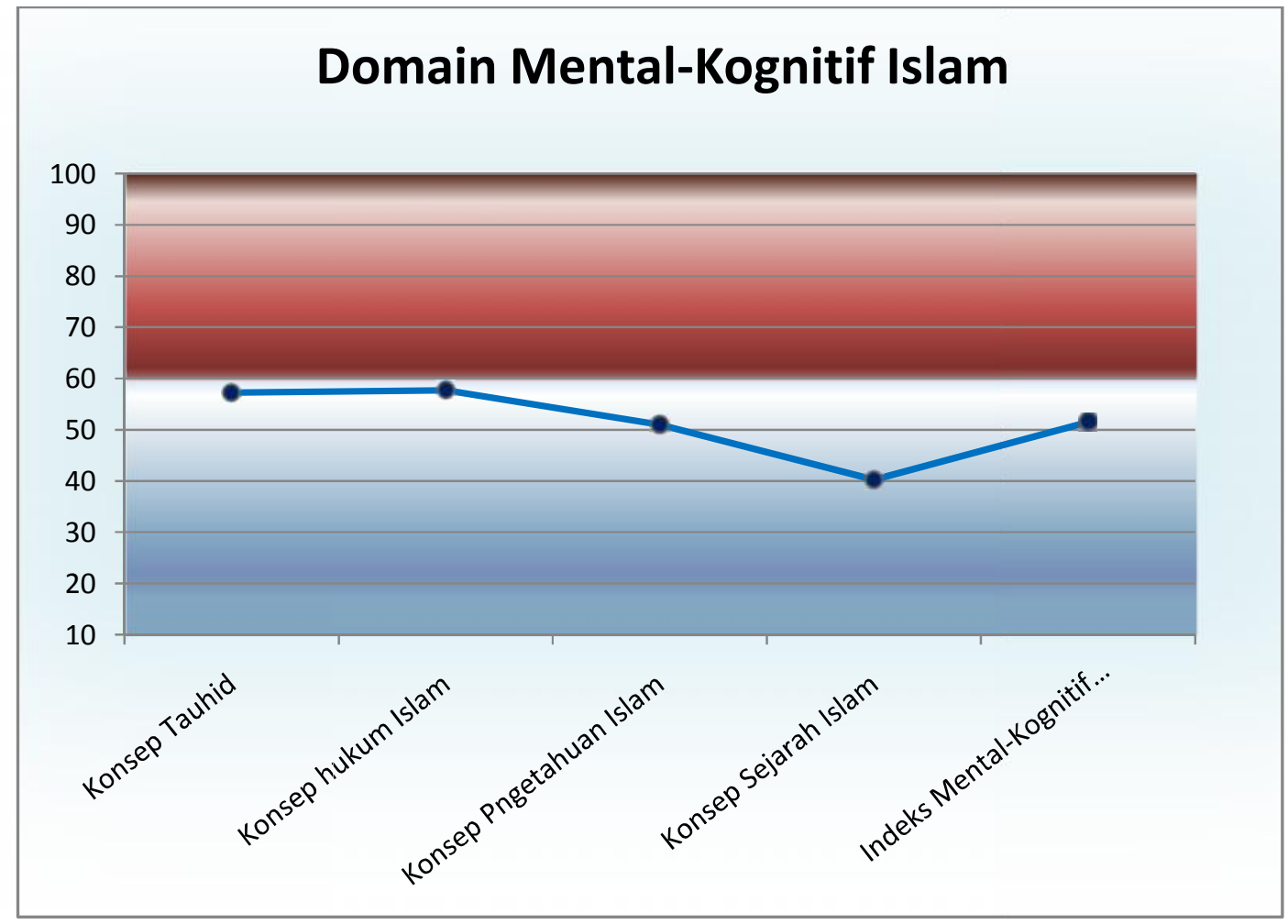

Rajah 1 Domain Mental-Kognitif Islam 
Khairil Anwar, Indeks Mental - Kognitif Islam : Satu Penanda Aras Psikospirtual Islam Remaja Berisiko

\begin{tabular}{|c|c|c|}
\hline Konstruk Mental-Kognitif & Islam Den & Skor Jantina \\
\hline \multirow[b]{2}{*}{ Konstruk Mental-Kognitif Islam } & \multicolumn{2}{|c|}{ Jantina } \\
\hline & Lelaki & Perempuan \\
\hline Tauhid & 55.67 & 59.10 \\
\hline Keadilan & 55.10 & 60.30 \\
\hline Musyawarah & 57.67 & 55.67 \\
\hline Jemaah & 51.20 & 48.80 \\
\hline Jenayah & 67.18 & 74.73 \\
\hline Sahsiah & 53.40 & 53.40 \\
\hline Muamalah & 65.22 & 68.22 \\
\hline Hukum Islam & 45.67 & 51.53 \\
\hline Pengetahuan Islam & 50.55 & 51.55 \\
\hline Ekonomi Islam & 47.22 & 51.78 \\
\hline Pengurusan Islam & 48.22 & 54.13 \\
\hline Keselamatan Dan Kesihatan Islam & 47.67 & 53.83 \\
\hline Sains Islam Islam & 52.83 & 54.75 \\
\hline Sejarah Islam & 42.52 & 37.30 \\
\hline
\end{tabular}

Jadual 3, menunjukkan Konstruk yang terdapat di dalam mental-kognitif Islam dan skor yang diperolehi berdasarkan jantina. Skor yang diperolehi bagi kumpulan lelaki dengan Konstruk tersebut ialah tauhid (55.67), keadilan (55.10), musyawarah (57.67), jemaah (51.20), Jenayah (67.18), sahsiah (53.40), muamalah (65.22), hukum Islam (45.67), Pengetahuan Islam(50.55), ekonomi Islam (47.22), pengurusan Islam (48.22),keselamatan dan kesihatan Islam (47.67), sains Islam (53.83) dan sejarah Islam (42.52).

Manakala skor yang diperolehi bagi kumpulan perempuan dengan konstruk tersebut ialah tauhid (59.10), keadilan (60.30), musyawarah (55.67), jemaah (48.80), jenayah (74.73), sahsiah (53.40), muamalah (68.22), hukum Islam (51.53), pengetahuan Islam(51.55), ekonomi Islam (51.78), pengurusan Islam (54.13), keselamatan dan kesihatan Islam (53.83), sains Islam (54.75) dan sejarah Islam (37.30). 


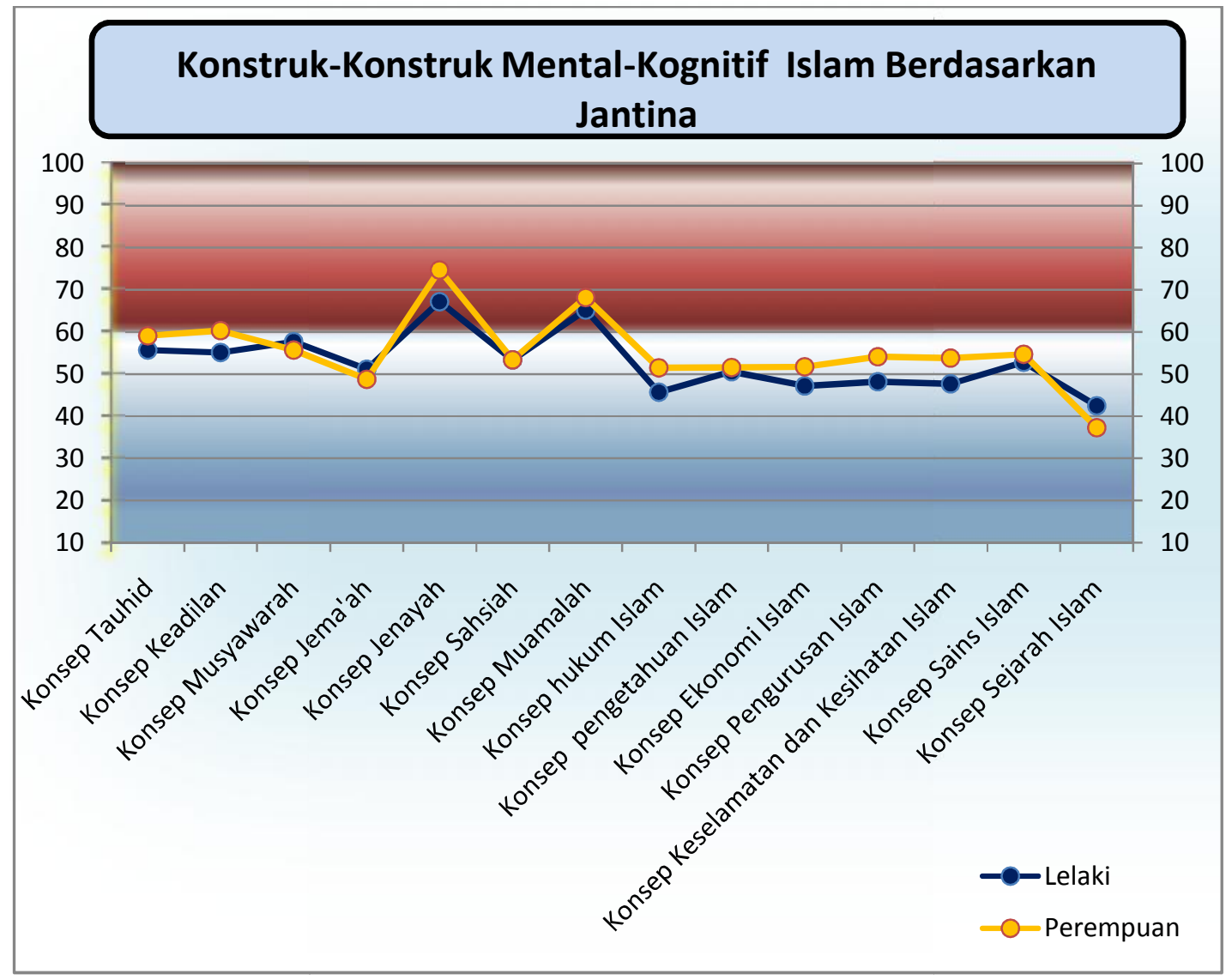

Rajah 3 Konstruk Mental-Kognitif Islam berdasarkan Jantina

Rajah 3 memperlihatkan bahawa responden lelaki dan perempuan samasama menempati skor terendah pada konstruk sejarah Islam. Pada konstruk ini skor perempuan (51.53) lebih tinggi berbanding lelaki (45.67). Demikian pula responden lelaki dan perempuan sama-sama menempati skor tertinggi pada konstruk konsep Jenayah. Pada konstruk ini skor perempuan (74.73) lebih tinggi berbanding lelaki (67.18). Secara umum skor perempuanlebih tinggi berbanding lelaki. 
Khairil Anwar, Indeks Mental - Kognitif Islam : Satu Penanda Aras Psikospirtual Islam Remaja Berisiko

\begin{tabular}{lcc}
\multirow{2}{*}{ Jadual 4} & Konstruk Mental-Kognitif Islam & \multicolumn{2}{c}{ Dengan Lokasi } \\
\cline { 2 - 3 } Konstruk Mental-Kognitif Islam & \multicolumn{2}{c}{ Lokasi } \\
\cline { 2 - 3 } Tauhid & Bandar & Bandar \\
\hline Keadilan & 57.81 & 56.71 \\
Musyawarah & 57.40 & 58.00 \\
Jemaah & 56.50 & 57.33 \\
Jenayah & 50.40 & 49.80 \\
Sahsiah & 72.53 & 68.93 \\
Muamalah & 54.80 & 51.60 \\
Hukum Islam & 66.89 & 66.56 \\
Pengetahuan Islam & 50.47 & 47.87 \\
Ekonomi Islam & 50.56 & 51.78 \\
Pengurusan Islam & 49.22 & 49.11 \\
Keselamatan Dan Kesihatan Islam & 52.53 & 48.33 \\
Sains Islam Islam & 51.67 & 48.33 \\
Sejarah Islam & 52.58 & 55.42 \\
& 40.47 & 39.97 \\
\hline
\end{tabular}

Berdasarkan jadual 4 menunjukkan konstruk yang terdapat di dalam mental-kognitif Islam dan skor yang diperolehi berdasarkan asal. skor yang diperolehi bagi responden yang berasal dari bandar dengan konstruk tersebut ialah tauhid (57.81), keadilan (57.40), musyawarah (56.50), jemaah (50.40) jenayah (72.53), sahsiah (54.80), muamalah (66.89), hukum Islam (50.47), pengetahuan Islam (50.56), ekonomi Islam (49.22), pengurusan Islam (52.53), keselamatan dan kesihatan Islam (51.67), sains Islam (52.58) dan sejarah Islam (40.47).

Manakala skor yang diperolehi bagi responden yang berasal dari luar bandar dengan konstruk tersebut ialah tauhid (56.71), keadilan (58.00), musyawarah (57.33), jemaah (49.80), jenayah (68.93), sahsiah (51.60), muamalah (66.56), hukum Islam (47.87), pengetahuan Islam (51.78), ekonomi Islam (49.11), pengurusan Islam (48.33), keselamatan dan kesihatan Islam (48.33), sains Islam (55.42) dan sejarah Islam (39.97). 


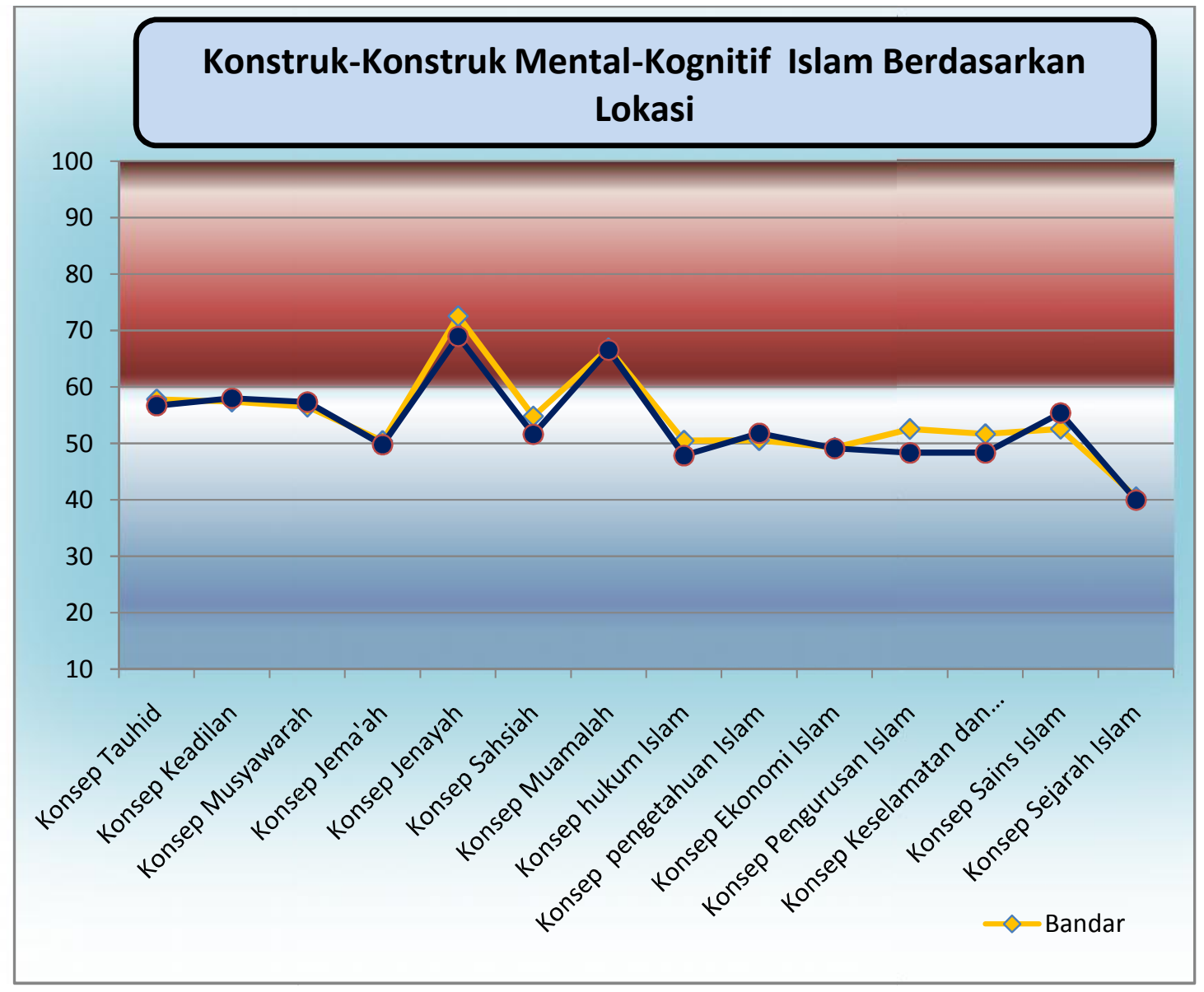

Rajah 4 Konstruk Mental-Kognitif Islam Berdasarkan Lokasi

Rajah 4 memperlihatkan bahawa responden asal bandar dan luar bandar sama-sama menempati skor terendah pada konstruk sejarah Islam. Pada konstruk ini skor asal bandar (40.47) lebih tinggi berbanding asal luar bandar (39.97). Demikian pula responden asal bandar dan luar bandar sama-sama menempati skor tertinggi pada konstruk konsep jenayah. Pada konstruk ini skor asal bandar (72.53) lebih tinggi berbanding asal luar bandar (68.93). secara umum skor Bandar dan luar Bandar adalah sama. 
Khairil Anwar, Indeks Mental - Kognitif Islam : Satu Penanda Aras Psikospirtual Islam Remaja Berisiko

Jadual 5 Konstruk Mental-Kognitif Islam Dengan Jenis Kesalahan

\begin{tabular}{|c|c|c|c|c|c|c|}
\hline \multirow[b]{2}{*}{$\begin{array}{l}\text { Konstruk } \\
\text { Mental-Kognitif Islam }\end{array}$} & \multicolumn{6}{|c|}{ Jenis kesalahan } \\
\hline & Seksual & Dadah & Mencuri & $\begin{array}{l}\text { Gengs } \\
\text { terisme }\end{array}$ & $\begin{array}{l}\text { Luar } \\
\text { kawalan }\end{array}$ & $\begin{array}{c}\text { Lari } \\
\text { dari } \\
\text { rumah }\end{array}$ \\
\hline Konsep tauhid & 58.04 & 57.00 & 57.00 & 55.47 & 61.47 & 58.05 \\
\hline Konsep keadilan & 60.50 & 59.40 & 55.60 & 55.00 & 58.90 & 59.30 \\
\hline Konsep musyawarah & 53.60 & 58.63 & 58.00 & 54.00 & 59.33 & 56.00 \\
\hline Konsep jemaah & 49.40 & 50.00 & 54.40 & 46.40 & 47.20 & 47.20 \\
\hline Konsep Jenayah & 66.67 & 73.33 & 68.93 & 67.80 & 66.73 & 69.53 \\
\hline Konsep sahsiah & 53.40 & 57.60 & 51.40 & 52.20 & 51.20 & 52.80 \\
\hline Konsep muamal & 59.89 & 70.33 & 64.11 & 65.89 & 69.56 & 68.00 \\
\hline $\begin{array}{l}\text { Konsep hukum Islam } \\
\text { Konsep pengetahuan }\end{array}$ & 50.93 & 49.73 & 49.60 & 45.20 & 51.60 & 50.80 \\
\hline Islam & 57.11 & 53.89 & 49.11 & 45.44 & 51.67 & 54.78 \\
\hline $\begin{array}{l}\text { Konsep ekonomi Islam } \\
\text { Konsep penqurusan }\end{array}$ & 50.67 & 49.78 & 49.33 & 45.67 & 51.56 & 50.67 \\
\hline $\begin{array}{l}\text { Islam } \\
\text { Konsep }\end{array}$ & 52.40 & 50.33 & 49.20 & 48.87 & 52.27 & 53.20 \\
\hline $\begin{array}{l}\text { keselamatan/kesihatan } \\
\text { Islam } \\
\text { Konsep sains Islam }\end{array}$ & 51.83 & 48.83 & 48.50 & 53.00 & 53.17 & 53.33 \\
\hline Islam & 54.67 & 54.83 & 51.83 & 51.67 & 55.67 & 55.25 \\
\hline Konsep sejarah Islam & 40.22 & 42.96 & 41.61 & 41.04 & 37.48 & 35.83 \\
\hline
\end{tabular}

Berdasarkan jadual 5 , menunjukkan konstruk yang terdapat di dalam mentalkognitif Islam dan skor yang diperolehi dengan jenis kesalahan. skor yang diperolehi bagi responden yang melakukan kesalahan seksual dengan konstruk tersebut ialah tauhid (58.04), keadilan (60.50), musyawarah (53.60), jemaah (49.40), jenayah (66.67), sahsiah (53.40), muamalah (59.89), hukum Islam (50.93), pengetahuan Islam (57.11), ekonomi Islam (50.67), pengurusan Islam (52.40), keselamatan dan kesihatan Islam (51.83), sains Islam (54.67) dan sejarah Islam (40.22).

Manakala skor yang diperolehi bagi responden yang melakukan kesalahan melibatkan dadah dengan konstruk tersebut ialah tauhid (57.00), keadilan (59.40), musyawarah (58.63), jemaah (50.00), jenayah (73.33), sahsiah (57.60), muamalah (70.33), hukum Islam (49.73), pengetahuan Islam (53.89), ekonomi Islam (49.78), pengurusan Islam (50.33), keselamatan dan kesihatan Islam (48.83), sains Islam (54.83) dan sejarah Islam (42.96). 
Bagi jenis kesalahan mencuri skor yang diperolehi dengan konstruk tersebut ialah tauhid (57.00), keadilan (55.60), musyawarah (58.00), jemaah (54.40), jenayah (68.93), sahsiah (51.40), muamalah (64.11), hukum Islam (49.60), pengetahuan Islam (49.11), ekonomi Islam (49.33), pengurusan Islam (49.20), keselamatan dan kesihatan Islam (48.50), sains Islam (51.83) dan sejarah Islam (41.61).

Skor yang diperolehi bagi responden yang melakukan kesalahan gangsterisme dengan konstruk tersebut ialah tauhid (55.47), keadilan (55.00), musyawarah (54.00), jemaah (46.40) jenayah (67.80), sahsiah (52.20), muamalah (65.89), hukum Islam (49.73), pengetahuan Islam (45.44), ekonomi Islam (45.67), pengurusan Islam (48.87), keselamatan dan kesihatan Islam (53.00), sains Islam (51.67) dan sejarah Islam (41.04).

Bagi jenis kesalahan luar kawalan skor yang diperolehi dengan konstruk tersebut ialah tauhid (61.47), keadilan (58.90), musyawarah (59.33), jemaah (47.20), jenayah (66.73), sahsiah (51.20), muamalah (69.56), hukum Islam(51.60), pengetahuan Islam (51.67), ekonomi Islam (51.56), pengurusan Islam (52.27), keselamatan dan kesihatan Islam (53.17), sains Islam (55.67) dan sejarah Islam (37.48).

Manakala skor yang diperolehi bagi responden yang melakukan kesalahan melibatkan dadah dengan konstruk tersebut ialah tauhid (57.00), keadilan (59.40), musyawarah (58.63), jemaah (50.00) jenayah (73.33), sahsiah (57.60), muamalah (70.33), hukum Islam (49.73), pengetahuan Islam (53.89), ekonomi Islam (49.78), pengurusan Islam (50.33), keselamatan dan kesihatan Islam (48.83), sains Islam (54.83) dan sejarah Islam (42.96).

Skor yang diperolehi bagi responden yang melakukan kesalahan lari dari rumah dengan konstruk tersebut ialah tauhid (58.05), keadilan (59.30), musyawarah (56.00), jemaah (47.20), jenayah (69.53), sahsiah (52.80), muamalah (68.00), hukum Islam (50.80), pengetahuan Islam (54.78), ekonomi Islam (50.67), pengurusan Islam (53.20), keselamatan dan kesihatan Islam (53.33), sains Islam (55.25) dan sejarah Islam (35.83). 
Khairil Anwar, Indeks Mental - Kognitif Islam : Satu Penanda Aras Psikospirtual Islam Remaja Berisiko

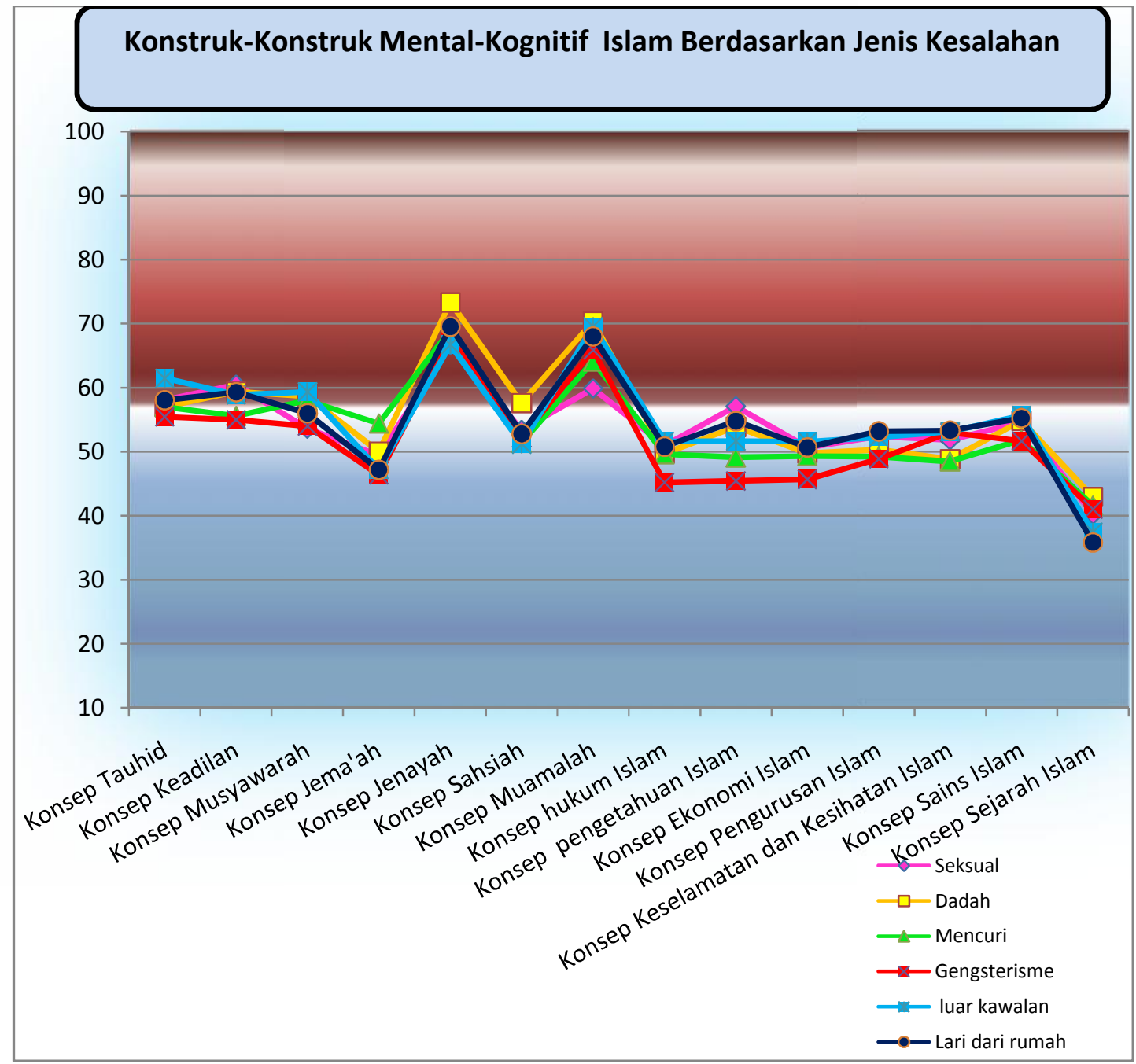

Rajah 5 Konstruk Mental-Kognitif Berdasarkan Jenis Kesalahan

Rajah 5 memperlihatkan bahawa responden mengikut jenis kesalahan adalah sama-sama menempati skor terendah pada konstruk sejarah Islam. Pada konstruk ini skor terendah terdapat pada jenis kesalahan lari dari rumah (35.83).. Demikian pula responden mengikut jenis kesalahan juga samasama menempati skor tertinggi pada konstruk konsep Jenayah. Pada konstruk ini skor jenis kesalahan dadah (73.33) menempati paling tinggi. Secara umum skor terendah adalah pada jenis kesalahan gangsterisma. 
Jadual 6 Konstruk Mental-Kognitif Islam Dengan Pendapatan

\begin{tabular}{|c|c|c|c|c|c|c|}
\hline \multirow{2}{*}{$\begin{array}{l}\text { Konstruk } \\
\text { Mental-Kognitif Islam }\end{array}$} & \multicolumn{6}{|c|}{ Pendapatan } \\
\hline & 1 & 2 & 3 & 4 & 5 & 6 \\
\hline Konsep tauhid & 51.95 & 58.29 & 56.05 & 67.95 & 65.00 & 60.52 \\
\hline Konsep keadilan & 50.00 & 57.00 & 56.60 & 67.70 & 64.50 & 56.40 \\
\hline Konsep musyawarah & 51.50 & 61.67 & 56.00 & 63.50 & 56.67 & 48.83 \\
\hline Konsep jemaah & 46.40 & 53.40 & 48.20 & 50.00 & 54.0 & 61.40 \\
\hline Konsep Jenayah & 64.93 & 70.60 & 70.8 & 78.46 & 79.33 & 74.73 \\
\hline Konsep sahsiah & 52.40 & 56.40 & 55.20 & 53.60 & 53.00 & 50.00 \\
\hline Konsep muamalah & 63.78 & 68.22 & 68.22 & 75.78 & 70.00 & 69.89 \\
\hline Konsep hukum Islam & 46.27 & 49.47 & 48.27 & 60.93 & 51.33 & 57.13 \\
\hline Konsep pengetahuan Islam & 45.78 & 54.67 & 53.33 & 57.11 & 57.78 & 52.33 \\
\hline Konsep ekonomi Islam & 42.78 & 52.56 & 51.33 & 56.11 & 49.44 & 49.22 \\
\hline $\begin{array}{l}\text { Konsep pengurusan Islam } \\
\text { Konsep keselamatan/ }\end{array}$ & 48.27 & 52.33 & 50.73 & 52.40 & 54.00 & 55.27 \\
\hline kesihatan Islam & 40.83 & 50.50 & 49.00 & 53.83 & 63.33 & 61.83 \\
\hline Konsep sains Islam Islam & 48.75 & 51.33 & 54.33 & 64.67 & 55 & 49.42 \\
\hline Konsep sejarah Islam & 40.96 & 37.70 & 40.96 & 36.57 & 41.96 & 43.17 \\
\hline
\end{tabular}

Keterangan : (1). RM 200-550, (2).RM 600-950, (3).RM 1000-2000, (4).RM. 2100-3000, (5).RM 3100-5000, (6).RM 6000 ke atas

Menerusi jadual 6, menunjukkan konstruk yang terdapat di dalam mental-kognitif Islam dan skor yang diperolehi dengan pendapatan keluarga. skor yang diperolehi bagi responden yang mempunyai pendapatan sebanyak RM 200-RM 550 dengan konstruk tersebut ialah tauhid (51.95), keadilan (50), musyawarah (51.5), jemaah (46.4), jenayah (64.93), sahsiah (52.4), muamalah (63.78), hukum Islam (46.27), pengetahuan Islam(45.78), ekonomi Islam (42.78), pengurusan Islam (48.27), keselamatan dan kesihatan Islam (40.83), sains Islam (48.75) dan sejarah Islam (40.96).

Manakala skor yang diperolehi bagi responden yang mempunyai pendapatan RM 600 -950 dengan konstruk tersebut ialah tauhid (58.29), keadilan (57), musyawarah (61.67), jemaah (53.4) jenayah (70.6), sahsiah (56.4), muamalah (68.22), hukum Islam (49.47), pengetahuan Islam(54.67), ekonomi Islam (52.56), pengurusan Islam (52.33), keselamatan dan kesihatan Islam (50.5), sains Islam (51.33) dan sejarah Islam (37.7).

Bagi pendapatan RM 1000 - RM 2000 skor yang diperolehi dengan konstruk tersebut ialah tauhid (56.05), keadilan (56.6), musyawarah (56), jemaah (48.2) jenayah (70.8), sahsiah (55.2), muamalah (68.22), hukum Islam (48.27), pengetahuan Islam (53.33), ekonomi Islam (51.33), 
Khairil Anwar, Indeks Mental - Kognitif Islam : Satu Penanda Aras Psikospirtual Islam Remaja Berisiko

pengurusan Islam (50.73), keselamatan dan kesihatan Islam (49), sains Islam (54.33) dan sejarah Islam (40.96).

Skor yang diperolehi bagi responden yang mempunyai pendapatan RM 2100 - RM 3000 dengan konstruk tersebut ialah tauhid (67.95), keadilan (67.7), musyawarah (63.5), jemaah (50), jenayah (78.46), sahsiah (53.6), muamalah (75.78), hukum Islam (60.93), pengetahuan Islam(57.11), ekonomi Islam (56.11), pengurusan Islam (52.4), keselamatan dan kesihatan Islam (53.83), sains Islam (64.67) dan sejarah Islam (36.57).

Bagi pendapatan RM 3100 - RM 5000 skor yang diperolehi dengan konstruk tersebut ialah tauhid (65), keadilan (64.5), musyawarah (56.67), jemaah (54), jenayah (79.33), sahsiah (53), muamalah (70), hukum Islam (51.33), pengetahuan Islam (57.78), ekonomi Islam (49.44), pengurusan Islam (54), keselamatan dan kesihatan Islam (63.33), sains Islam (55) dan sejarah Islam (41.96).

Manakala skor yang diperolehi bagi responden yang berpendapatan RM 6000 ke atas dengan konstruk tersebut ialah tauhid (60.52), keadilan (56.4), musyawarah (48.83), jemaah (61.4), jenayah (74.73), sahsiah (50), muamalah (69.89), hukum Islam (57.13), pengetahuan Islam(52.33), ekonomi Islam (49.22), pengurusan Islam (55.27), keselamatan dan kesihatan Islam (61.83), sains Islam (49.42) dan sejarah Islam (43.17). 


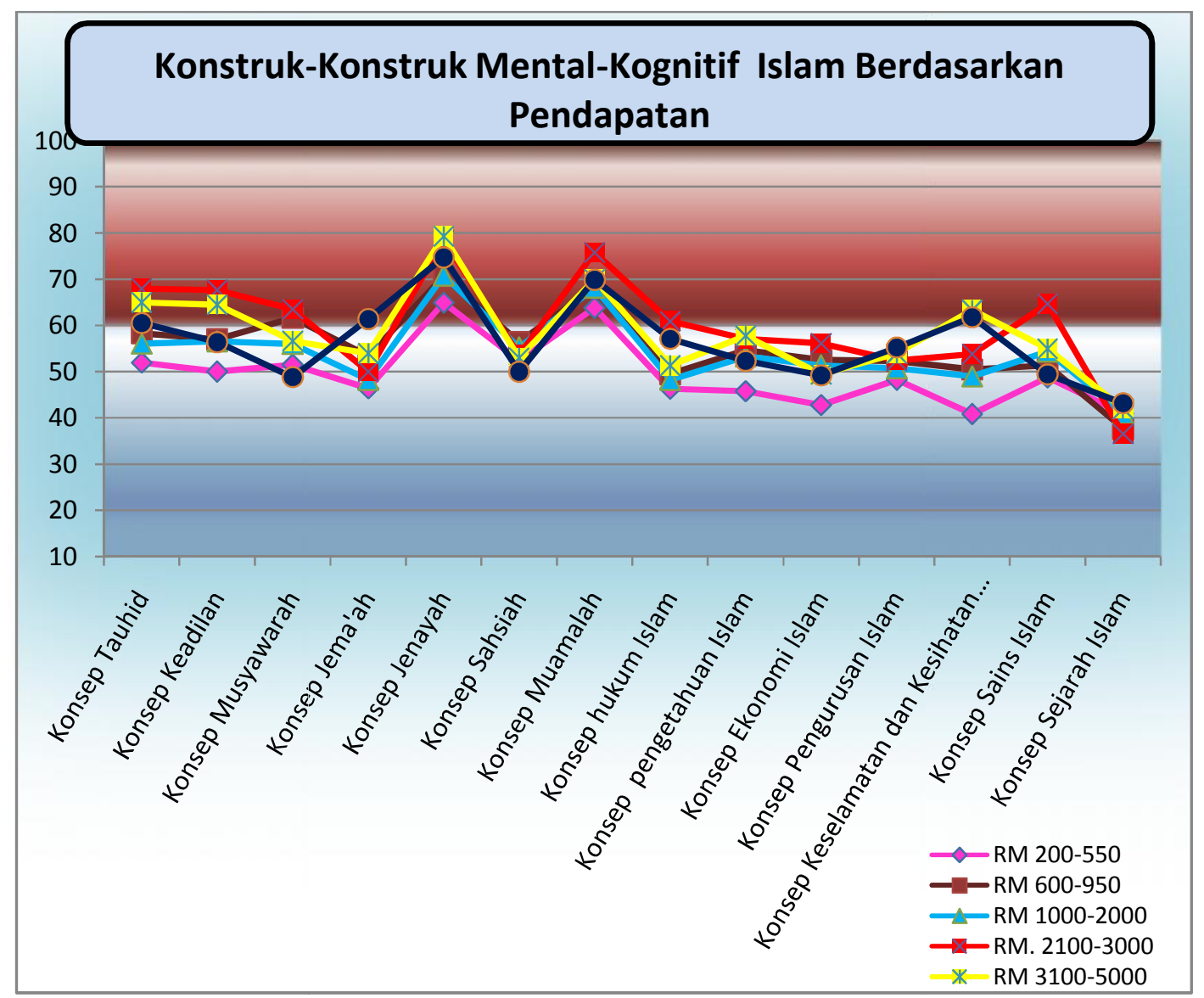

Rajah 6 Konstruk Mental-Kognitif Islam Berdasarkan Pendapatan

Rajah 6 memperlihatkan bahawa responden dengan pendapatan keluarga RM. 200-550 (40.83) skor yang terendah adalah pada konstruk keselamatan dan kesihatan. Manakala Responden selain berpendapatan RM. 200-550 menempati skor terendah pada kosep sejarah Islam. Mengikut tahap pendapatan ini secara keseluruhan, menempati skor yang tertinggi pada Konsep Jenayah. Secara umum skor setiap konstruk yang terendah adalah terdapat pada kumpulan pendapatan RM. 200-550. 
Khairil Anwar, Indeks Mental - Kognitif Islam : Satu Penanda Aras Psikospirtual Islam Remaja Berisiko

Jadual 7 Konstruk Mental-Kognitif Islam Dengan Tahap Umur

\begin{tabular}{lccc}
\hline & \multicolumn{3}{c}{ Tahap umur } \\
\cline { 2 - 4 } Konstruk & $\begin{array}{c}\text { 13-15 tahun } \\
\text { (Remaja } \\
\text { awal) }\end{array}$ & $\begin{array}{c}\text { 16-18 tahun } \\
\text { (Remaja } \\
\text { pertengahan) }\end{array}$ & $\begin{array}{c}19-22 \\
\text { tahun } \\
\text { (Remaja } \\
\text { akhir) }\end{array}$ \\
\hline Konsep tauhid & 50.43 & 57.95 & 57.71 \\
Konsep keadilan & 45.70 & 58.60 & 58.80 \\
Konsep musyawarah & 45.67 & 56.50 & 59.50 \\
Konsep jemaah & 43.00 & 50.60 & 51.00 \\
Konsep Jenayah & 59.73 & 72.20 & 71.60 \\
Konsep sahsiah & 45.20 & 55.00 & 53.20 \\
Konsep muamalah & 57.44 & 67.67 & 67.67 \\
Konsep hukum Islam & 40.00 & 49.73 & 51.00 \\
Konsep pengetahuan Islam & 40.00 & 51.22 & 53.22 \\
Konsep ekonomi Islam & 43.00 & 50.22 & 49.67 \\
Konsep pengurusan Islam & 43.53 & 52.07 & 50.53 \\
Konsep keselamatan / & & & \\
kesihatan Islam & 45.00 & 50.33 & 50.67 \\
Konsep sains Islam Islam & 45.33 & 54.67 & 54.00 \\
Konsep sejarah Islam & 35.61 & 39.96 & 41.52 \\
\hline
\end{tabular}

Berdasarkan jadual 7 , menunjukkan konstruk yang terdapat di dalam mental-kognitif Islam dan skor yang diperolehi dengan tahap umur. skor yang diperolehi bagi responden yang berumur $13-15$ tahun (remaja awal) dengan konstruk tersebut ialah tauhid (50.43), keadilan (45.70), musyawarah (45.67), jemaah (43.00), jenayah (59.73), sahsiah (45.20), muamalah (57.44), hukum Islam (40.00), pengetahuan Islam(40.00), ekonomi Islam (43.00), pengurusan Islam (43.53), keselamatan dan kesihatan Islam (45.00), sains Islam (45.33) dan sejarah Islam (35.61).

Manakala skor yang diperolehi bagi responden yang berumur $16-18$ tahun (remaja pertengahan) dengan konstruk tersebut ialah tauhid (57.95), keadilan (58.60), musyawarah (56.50), jemaah (50.60) jenayah (72.20), sahsiah (55.00), muamalah (67.67), hukum Islam (49.73), pengetahuan Islam(51.22), ekonomi Islam (50.22), pengurusan Islam (52.07), keselamatan dan kesihatan Islam (50.33), sains Islam (54.67) dan sejarah Islam (39.96).

Bagi responden yang berumur $19-22$ tahun (remaja akhir) skor yang diperolehi dengan konstruk tersebut ialah tauhid (57.71), keadilan (58.80), musyawarah (59.50), jemaah (51.00) jenayah (71.60), sahsiah (53.20), 
Al-Fikra: Jurnal IImiah Keislaman, Vol.14, No.2, Juli - Desember 2015

muamalah (67.67), hukum Islam (51.00), pengetahuan Islam(53.22), ekonomi Islam (49.67), pengurusan Islam (50.53), keselamatan dan kesihatan Islam (50.67), sains Islam (54.00) dan sejarah Islam (41.52).

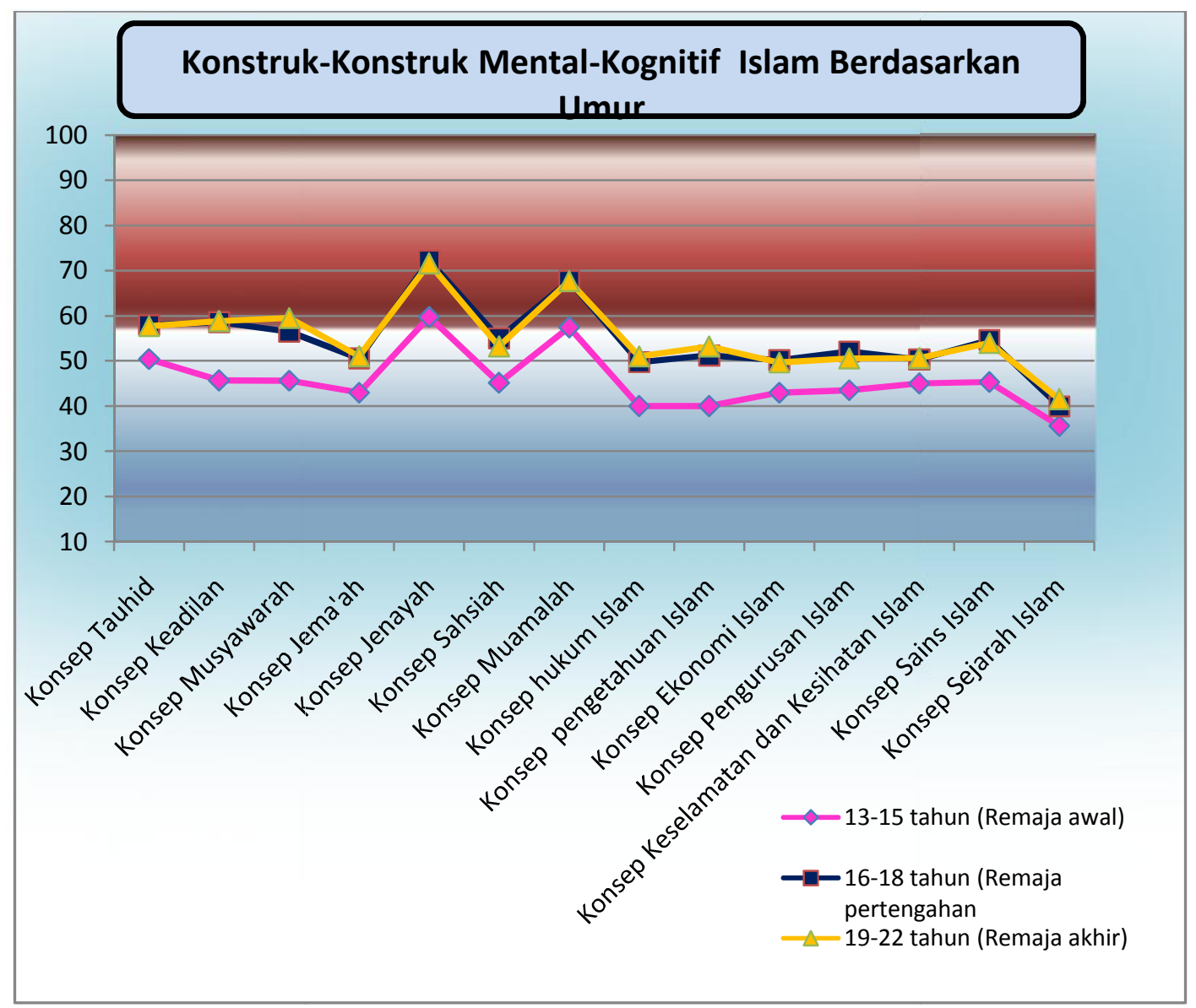

Rajah 7 Konstruk Mental-Kognitif Islam Berdasarkan Umur

Rajah 7 memperlihatkan bahawa responden mengikut umur adalah samasama menempati skor terendah pada konstruk sejarah Islam. Pada konstruk ini skor terendah terdapat pada tahap umur 13-15 tahun (35.61).. Demikian pula responden mengikut umur juga sama-sama menempati skor tertinggi pada konstruk konsep Jenayah. Pada konstruk ini skor tahap umur 16-18 tahun (72.20) menempati paling tinggi. Secara umum skor terendah pada konstruk Mental-kognitif Islam adalah dalam kumpulan umur 13-15 tahun sebagai yang disebut remaja awal. 
Khairil Anwar, Indeks Mental - Kognitif Islam : Satu Penanda Aras Psikospirtual Islam Remaja Berisiko

Jadual 8 Konstruk Mental-Kognitif Islam dengan Tahap Sekolah Responden

\begin{tabular}{lccc}
\hline & \multicolumn{3}{c}{ Tahap Sekolah } \\
\cline { 2 - 4 } Konstruk & $\begin{array}{c}\text { Sekolah } \\
\text { rendah/ } \\
\text { tidak } \\
\text { sekolah }\end{array}$ & $\begin{array}{c}\text { Sekolah } \\
\text { menengah }\end{array}$ & $\begin{array}{c}\text { Sekolah } \\
\text { kemahiran }\end{array}$ \\
\hline Konsep tauhid & 44.62 & 60.05 & 58.81 \\
Konsep keadilan & 47.30 & 59.40 & 60.00 \\
Konsep musyawarah & 49.67 & 59.33 & 57.00 \\
Konsep jemaah & 45.80 & 51.00 & 52.80 \\
Konsep Jenayah & 62.07 & 73.33 & 73.47 \\
Konsep sahsiah & 52.40 & 54.60 & 52.00 \\
Konsep muamalah & 59.78 & 69.22 & 66.22 \\
Konsep hukum Islam & 41.53 & 51.53 & 52.13 \\
Konsep pengetahuan Islam & 43.22 & 54.11 & 51.56 \\
Konsep ekonomi Islam & 40.44 & 50.89 & 48.44 \\
Konsep pengurusan Islam & 40.73 & 52.20 & 53.47 \\
Konsep keselamatan/kesihatan & & & \\
Islam & 40.17 & 53.00 & 46.00 \\
Konsep sains Islam Islam & 43.83 & 56.83 & 52.75 \\
Konsep sejarah Islam & 35.78 & 40.78 & 46.09 \\
\hline
\end{tabular}

Menerusi jadual 8, menunjukkan konstruk yang terdapat di dalam mental-kognitif Islam dan skor yang diperolehi dengan tahap pendidikan. skor yang diperolehi responden yang tahap pendidikan sehingga sekolah rendah/tidak bersekolah dengan konstruk tersebut ialah tauhid (44.62), keadilan (47.30), musyawarah (49.67), jemaah (45.80) jenayah (62.07), sahsiah (52.40), muamalah (59.78), hukum Islam (41.53), pengetahuan Islam (43.22), ekonomi Islam (40.44), pengurusan Islam (40.73), keselamatan dan kesihatan Islam (40.17), sains Islam (43.83) dan sejarah Islam (35.78).

Manakala skor yang diperolehi responden yang tahap pendidikan sehingga sekolah menengah dengan konstruk tersebut ialah tauhid (60.05), keadilan (59.40), musyawarah (59.33), jemaah (51.00), jenayah (73.33), sahsiah (54.60), muamalah (69.22), hukum Islam (51.53), pengetahuan Islam(54.11), ekonomi Islam (50.89), pengurusan Islam (52.20), keselamatan dan kesihatan Islam (53.00), sains Islam (56.83) dan sejarah Islam (40.78).

Bagi responden yang tahap pedidikan sehingga sekolah kemahiran skor yang diperolehi dengan konstruk tersebut ialah tauhid (58.81), keadilan (60.00), musyawarah (57.00), jemaah (52.80) jenayah (73.47), sahsiah 
Al-Fikra: Jurnal IImiah Keislaman, Vol.14, No.2, Juli - Desember 2015

(52.00), muamalah (66.22), hukum Islam (52.13), pengetahuan Islam (51.56), ekonomi Islam (48.44), pengurusan Islam (53.47), keselamatan dan kesihatan Islam (46.00), sains Islam (52.75) dan sejarah Islam (46.09).

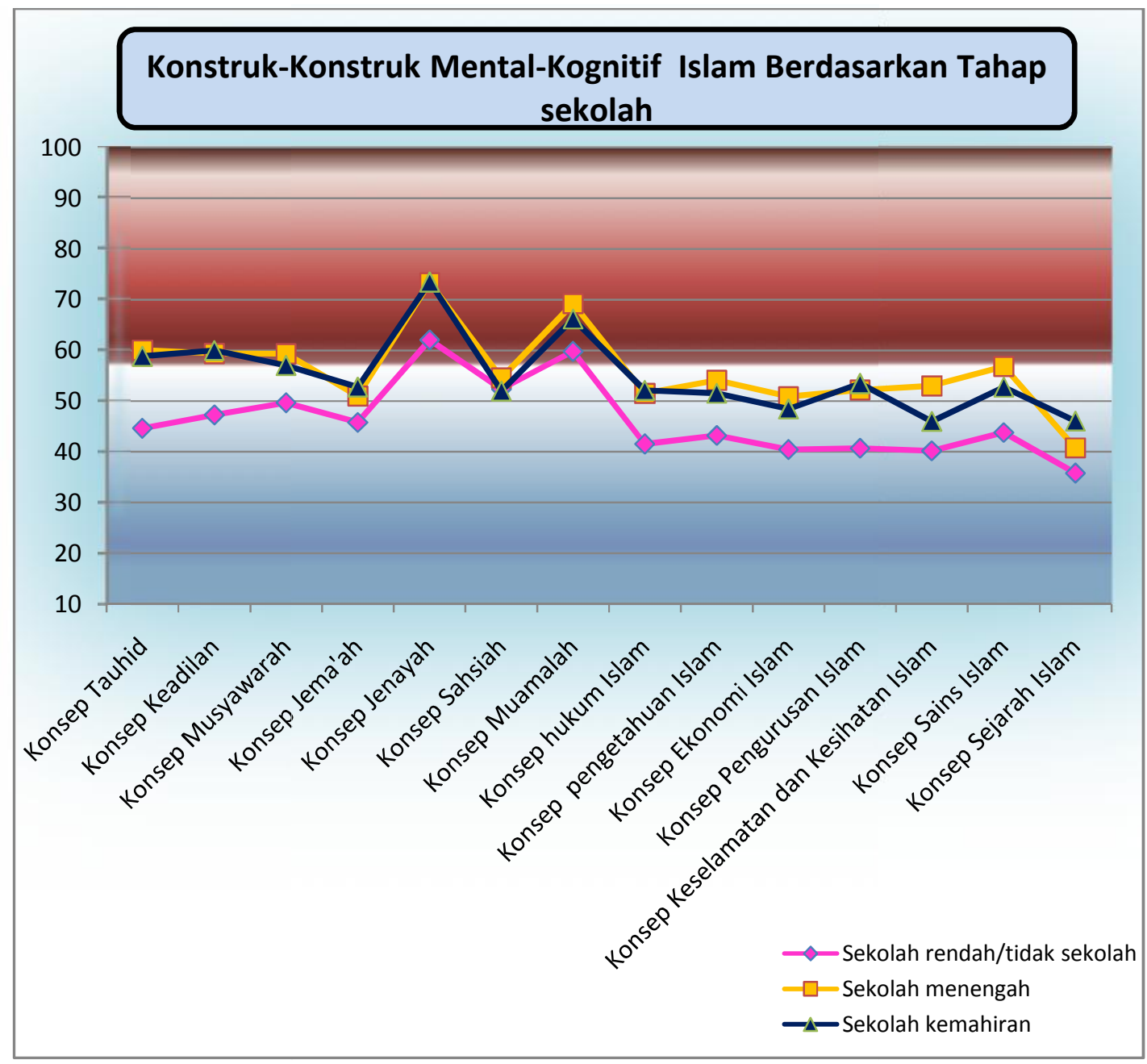

Rajah 8 Konstruk Mental-Kognitif Islam Berdasarkan Tahap Sekolah Rajah 8 memperlihatkan bahawa responden mengikut tahap sekolah adalah sama-sama menempati skor terendah pada konstruk sejarah Islam. Pada konstruk ini skor terendah terdapat pada tahap sekolah rendah/tidak bersekolah (35.78).. Demikian pula responden mengikut tahap sekolah juga sama-sama menempati skor tertinggi pada konstruk konsep Jenayah. Pada konstruk ini skor tahap sekolah kemahiran (73.47) menempati paling tinggi. Secara umum skor konstruk mental-kognitif Islam yang paling rendah adalah 
Khairil Anwar, Indeks Mental - Kognitif Islam : Satu Penanda Aras Psikospirtual Islam Remaja Berisiko

dalam kumpulan tahap sekolah rendah/tidak bersekolah. Dan yang paling tinggi adalah pada kumpulan sekolah menengah.

\section{Pembahasan}

Secara umum profil mental kognitif islam diukur dengan skor di bawah 60 adalah aras rendah dan 60 ke atas adalah aras tinggi. Kajian ini remaja berisiko berada pada paras skor yang rendah (51.56). Mental-kognitif yang menggambarkan cara berfikir bathiniyyah (mental) remaja adalah suatu konsep penting yang akan menetukan sikap dan tingkahlaku remaja dalam persekitaran yang penuh dengan pelbagai gejala sosial. Mental kognitif islam yang jauh adalah suatu aspek yag merupakan cara pandang kehidupan seorang muslim dari sudut agama yang diyakini secara mendalam dan lebih cenderung lebih mengutamakan dalaman daripada simbol luaran. Indikatorindikator yang terdapat dalam pengukuran mental-kognitif Islam ini dibina secara khas untuk melakukan penilaian. Rendahnya aras mental kognitif islam remaja adalah salah satu yang boleh dijadikan indikator mengapa terjadinya tingkahlaku anti sosial dalam kalangan remaja.

Pengukuran Mental kognitif ini dibina bertujuan untuk menggambarkan pemikiran dan amalan keagamaan yang bersifat abstrak bukan yang kongkrit. Salah satu contoh item " boleh berpelukan dan bercumbu asal tidak berzina". Item ini adalah bersifat abstrak untuk mengukur kecendrungan tingkahlaku zina, dan bukan mengukur hukum berzina. Bagi seseorang yang befikiran kongkrit akan menjawab ya, kerana mereka akan terpengaruh dengan hukum perilaku berzina. Namun bagi mereka yang berfikiran abstrak mereka akan menjawab tidak, kerana mereka akan mendahulukan kejadian dan hukum sesuatu perkara bergantung pada sebab dan akibat (kausaliti). Kebanyakan remaja berisiko dalam kajian ini menjawab ya. Seperti item " boleh menjual arak kepada orang bukan Islam", kebanyakan remaja dalam kajian ini menjawab ya. Jawapan ini menunjukkan betapa rendahnya mental kognitif remaja dalam menilai hukum halalnya suatu perbuatan. Mereka lebih mendahulukan hukum haram meminum arak, dan mereka abaikan hukum menjualnya. Dalam tradisi pendidikan pengajaran Islam, kurikulum pendidikan Islam hanya mengajar tentang hukum halal sesuatu perbuatan ataupun zat, namun dari segi perbuatan lainnya diabaikan. Seperti yang kita ketahui, hukum meminum arak dan menjual arak untuk orang muslim adalah haram. Namun menjual arak untuk orang yang bukan muslim tidak mendapat penjelasan yang baik. Seakan-akan zat haram hanya dilarang untuk orang Islam, padahal hukum yang ditetapkan Allah adalah untuk semua manusia. Setiap orang islam wajib melarang orang lain melakukan perbuatan haram, dan hasil penjualan zat haram hukumnya adalah haram serta membantu menyediakan benda haram hukumnya adalah haram. Pemahaman holistik ini 
Al-Fikra: Jurnal IImiah Keislaman, Vol.14, No.2, Juli - Desember 2015

membawa impak sosial yang luas untuk mencegah berlakunya gejala sosial, khususnya gejala sosial dalam kalangan remaja Islam.

Rendahnya aras mental kognitif remaja Islam membawa makna yang sangat signifikan tentang pemahaman islam yang syumul dalam kalangan remaja berada dalam keadaan kritikal. Aktiviti jenayah akan terus berlaku dalam kalangan remaja, selagi aras mental kognitif islam tidak ditingkatkan secepat mungkin.

Keyakinan sebagai salah satu asas penting mental kognitif Islam untuk memperbaiki sikap dan tingkahlaku manusia, khususnya bagi para remaja. Keyakinan ini dapat mematahkan pertumbuhan pemikiran yang materialisma dalam kalangan remaja, dan menyuburkan semangat bekerja dan berusaha. Allah SWT mewajibkan kita berusaha namun menjatuhkan hukum haram meyakini apa yang diusahakan merupakan pemikiran yang bagus. Pola berfikir ini adalah bentuk kesejahteraan psikologi yang berlandaskan Islam. Tauhid sebagai asas utama Psikologi Islam tidak jumud, namun ia dapat mencerdaskan akal manusia agar tidak dibelenggu oleh pemikiran materilispositivisma, sebagai pemacu tingkahlaku yang cenderung ke arah anti sosial.

Ketauhidan yang benar dan lurus akan menerangi kehidupan masyarakat dengan pancaran cahayanya, sekaligus memberi pengaruh luar biasa terhadap dimensi kehidupan sama ada dalam pemikiran, pemahaman, perasaan, akhlak mahupun aturan. Keimanan adalah proses kejiwaan yang berkaitan dengan dimensi rohani, meliputi akal, keinginan dan perasaan manusia. (Yusuf, Muhammad al-Sayyid dan Durrah, Ahmad. 2008) Qardawi (2007) mengatakan jika dikaitkan dengan individu dan masyarakat, iman merupakan benteng yang mampu menjaganya dari kebinasaan dan pelbagai marabahaya. Kehidupan yang terlepas daripada iman adalah kehidupan yang tidak mengandung kebajikan, kemuliaan dan peri kemanusiaan. Unsur keburukan, kerosakan, dan marabahaya akan subur di dalam jiwa. Individu atau masyarakat yang hidup tanpa iman dan agama bagaikan anai-anai yang ditiup angin; sangat rapuh, lemah, hilang tujuan hidup, terasing, mudah terombang ambing kesana kemari, sentiasa berasa tidak tenang, tidak memiliki halatuju hidup yang jelas, sentiasa berasa bimbang, serta tidak memahami hakikat diri dan rahsia dirinya diciptakan. 
Khairil Anwar, Indeks Mental - Kognitif Islam : Satu Penanda Aras Psikospirtual Islam Remaja Berisiko

\section{DAFTAR PUSTAKA}

Cattell, R.B. 1963. Theory of fluid and crystallized intelligence: A critical experiment. J ournal of Educational P sychology 54, 1-22.

Fuad Amsyari. 1995. Islam Kaaffah: tantangan sosial dan aplikasinya di Indonesia. Jakarta: Gema Insani press.

Halstead, B. 1992. Young people as victims of violence. Tasmania: National clearinghouse for youth studies.

Hamzah Ya'qub. 1983. Etika islam pembinaan akhlakul karimah. Bandung: CV. Diponegoro.

Khaidzir Hj. Ismail \& Khairil Anwar. 2011. Psikologi Islam : Suatu Pendekatan Psikometrik Remaja Berisiko (Islamic Psychology: An Approach To Psychometric For At-Risk Adolescence). J urnal E-Bangi 6(1): 77-89.

Khaidzir Hj. Ismail. 2007. Profile of At-Risk Female Adolescent: A Case Study in Selangor. INMIND, National.

Saifuddin Azwar. 1996. Psikologi Intelegensi. Yogyakarta : Pustaka Belajar.

Samsudin A. Rahim et al. 2006. Indeks Belia Malaysia. Putra Jaya: Institut Penyelidikan Pembangunan Belia Malaysia (IPPBM).

Yahya, harun. 2002. Moralitas AI-Qur'an; S olusi Atas Segala Persoalan Umat Manusia. Jakarta; Rabbani Press.

Yusuf, al-Sayyid, Muhammad \& Durrah, Ahmad. 2008. Pustaka Pengetahuan al-Qur'an: IImu Pengetahuan. Volume ke-6. Jakarta: PT. Rehal Republika. 


\title{
INDEKS MENTAL-KOGNITIF ISLAM: SATU PENANDA ARAS PSIKOSPIRTUAL ISLAM REMAJ A BERISIKO
}

\author{
Khairil Anwar \\ E-mail :karkun74@gmail.com \\ Universitas Islam Negeri Sultan SyarifKasimRiau
}

\begin{abstract}
The purpose of this study was to describe the Islamic Mentalcognitive index on risk youth. Islamic Mental-cognitive termed a structure depths of human childbirth perception, introspection, memory, creativity, imagination, conception, belief, reasoning, volition, and emotions as a unified way of thinking based on Islam, is an attempt to predict and as approaches to identify the problem and solve psychological risk youth. Six recovery centers have been chosen for this study, involving busy as 490 coaches and 128 students of a secondary school of nationality as a collection of the convoy. Background to the economic status of parents of respondents also identified and data collection is done using inquired about the accreditation forms which contains a measurement of Islamic Mental-cognitive. Data were analyzed using a mathematical formula to form the Islamic Mental-cognitive index that consists of multiple domains. Decision of the study showed an index of Islamic Mental-cognitive is at the stage of a low (score 51.56). The discovery of this study backs up one module coaching intervention and prevention against socio-psychological symptoms teens through the principles of the concept of Islamic Mental-cognitive, Islamic psychosocial and sunnah behavior.
\end{abstract}

Key words : Islamic Mental-cognitive, Islamic psycho-spiritual and risk youth.

\section{PENDAHULUAN}

Kemajuan teknologi tanpa diiringi oleh kecerdasan agama dalam konteks Islam disebut dengan kecerdasan tauhid (Tauhidic quotiens), akan membawa kerendahan budi dan adab terutama dalam kalangan remaja. Seperti kemajuan teknologi media massa, apabila tidak mendapat kawalan dapat membawa ke arah keruntuhan akhlak. Maka dalam tuntutan agama, orang yang bertanggungjawab menanamkan nilai agama tersebut adalah orang tua, masyarakat, pemimpin, dan ulama. Apabila di antara unsur-unsur masyarakat yang dimaksudkan mengabaikan dan tidak peduli pada perilaku dan akhlak remaja, maka dengan sendirinya akan terlahirlah remaja remaja yang bermasalah. (Hamzah Ya'qub 1983).

Dalam konteks Malaysia dan Negara Islam sedang membangun, hal yang sangat membimbangkan adalah masalah pergaulan bebas yang mengheret kepada permasalahan besar iaitu jenayah pembunuhan dan 
Al-Fikra: Jurnal IImiah Keislaman, Vol.14, No.2, Juli - Desember 2015

pembuangan bayi. Pergaulan bebas yang ditandai dengan kebebasan melakukan kontidak seksual dalam kalangan remaja sudah menjadi hal yang biasa dan lumrah. Seperti penyelidikan Khaidzir Hj Ismail (2007) seorang Pakar Kanak-kanak dan Psikologi Remaja, mendapati dari 887 remaja sekitar 13 ke 17 tahun yang dikaji, dijumpai hanya hanya satu orang sahaja yang mengaku tidak pernah mengadakan hubungan seks. Selain hubungan seks haram, murid-murid ini turut mengaku ada terlibat dalam kegiatan dadah, kongsi gelap, pornografi, vandalisma dan ponteng.

Selain itu pembunuhan adalah kes jenayah dunia yang sangat dikhawatirkan saat ini, kerana yang melakukan adalah kanak kanak (baca: remaja), artinya terjadi suatu arus jenayah pembunuhan dalam kalangan kanak kanak. Di Amerika terjadi penembakan oleh kanak sekolah dengan melakukan serangkaian pembantaian yang mengerikan, walaupun usianya masih muda. Peningkatan angka kanak-kanak membunuh telah menjadi tragedi besar kemanusiaan. (Harun Yahya 2002). Dalam laporan Halstead (1992), bahawa remaja yang membunuh di Australia berada pada peringkat ke tiga terbesar melakukan pembunuhan, yakni terjadi 44 kes pembunuhan dalam setiap 100,000 orang penduduk pada tahun 1998-90. Hal ini disebabkan oleh Otidak kanak - kanak telah dipengaruhi oleh program TV dan filem yang dipenuhi dengan kekerasan dalam proporsi yang tidak pernah terjadi sebelumnya. Tayangan pembunuh mendominasi beberapa filem tertentu dan berisiko bagi kanak kanak. (Harun Yahya 2002).

Hal yang mendorong para remaja ke dalam persekitaran gelap dan membuat mereka mudah terlibat dengan kekejaman adalah disebabkan mereka hidup berdampingan dengan orang-orang dewasa yang jauh daripada agama. Orang yang tidak takut pada Allah akan melahirkan generasi keji yang tidak takut pada Allah. Mereka menanamkan dalam diri anak-anak mereka perbuatan keji dan bukannya keimanan, belas kasih, dermawan, kejujuran, kebijaksanaan. (Harun Yahya 2002). Terjadinya kejahatan yang dilakukan oleh kanak-kanak bukanlah suatu keanehan, kerana dalam mayarakat tersebut kanak kanaknya tidak diperkenalkan dengan nilai-nilai Islam dan akhlakul karimah. (Harun Yahya 2002). Maka di dalam ajaran Islam dikatakan bahawa perintah melakukan amar ma'ruf nahi munkar adalah syarat mutlak untuk mencegah kemungkaran dan kemaksiatan (Fuad Amsyari 1995), tujuan penganjuran ini dilaksanakan untuk mengantisipasi gejala salah laku dalam kalangan remaja.

Selain daripada dapatan data statistik di atas, dapatan yang ingin dilihat adalah keadaan psikologi remaja yang telah melakukan salah laku yang dimaksud. Kerana faktor dalaman yang akan menjadi pendorong terjadinya sesebuah tingkahlaku. Maka kajian ini cuba melengkapi kajiankajian salah laku remaja yang sedia ada, yang hanya melihat angka-angka 
Khairil Anwar, Indeks Mental - Kognitif Islam : Satu Penanda Aras Psikospirtual Islam Remaja Berisiko

statistik, kepada suatu kajian untuk mengungkapkan fenomena psikologi remaja yang menyebabkan mereka terjebak dalam perbuatan salah laku.

\section{Mental-kognitif Islam}

Dalam banyak literatur sering menyamakan makna antara mental dan kognitif. Kedua konsep ini selalu dimaksudkan dengan erti berfikir. Penyamaan makna kedua konsep ini tidak diketepikan, kerana memang keduanya merujuk kepada proses manusia berfikir. Lebih jauh apabila kedua konsep ini ditelusuri secara mendalam, maka didapati titik perbezaan untuk menerangkan proses manusia berfikir.

Kognitif secara umum adalah suatu proses yang lebih mengarah kepada proses penemuan suatu maklumat atau pengenalan kembali suatu maklumat. Dalam erti kata lain kognitif adalah suatu proses kemampuan manusia berfikir untuk mengenali dan menenmukan maklumat sama ada yang bersumber daripada dalaman manusia mahupun yang bersumber daripada luaran manusia atau faktor persekitaran. Manakala mental adalah motor penggerak dan abstraksi dari proses kognitif yang menghubungkan pola-pola berfikir dengan alam kesedaran manusia, di mana manusia sedar bahawa sedang terjadi proses berfikir yang pada akhirnya kegiatan mental inilah yang akan menjadi titik utama dalam penyelesaian masalah. Jadi dapat dikatakan bahawa mental kognitif adalah proses kecerdasan seseorang menangani masalah dari input-input luaran dan dalaman manusia.

Sebagai perbandingan dapat dirujuk dari teori Cattel (1963) mengenai organisasi mental, beliau mengklasifikasi kemampuan mental menjadi dua jenis, iaitu intelegensi fluid yang merupakan faktor semula jadi biologikal dan kecerdasan crystallized yang mereflaksikan adanya pengaruh pengalaman, pendidikan, budaya dan kebiasaan dalam diri seseorang individu.

Dari teori Cattel ini berkemungkinan dapat dianalogikan proses mental kognitif adalah berlangsung dari dua jenis kemampuan mental di atas. Ertinya secara semula (fluid) jadi setiap orang telah membawa potensi mental kognitif untuk memproses cara berfikirnya, manakala kualiti mental kognitif bergantung kepada persekitaran (crystallized). Tahap Mental kognitif yang baik akan mempengaruhi cara seseorang individu untuk dapat memahami dan menyelesaikan masalah dengan baik. Seiring dengan ini, Mohammad Saleh (2007) menggambarkan bahawa kemampuan kognitif seseorang yang beramal dengan ikhlas, sangat berpengaruh terhadap pola coping seseorang individu untuk menyelesaikan sesuatu masalah.

Dengan demikian menurut Saifuddin Azwar (1996) intelegensi crystallized dapat dipandang sebagai intipati pengalaman yang terjadi sewaktu intelegensi fluid bercampur dengan apa yang disebut intelegensi budaya. Intellegensi crystallized akan meningkat dalam diri seseorang, seiring dengan bertambahnya pengalaman. Dengan kata lain, tugas tugas 
Al-Fikra: Jurnal IImiah Keislaman, Vol.14, No.2, Juli - Desember 2015

kognitif adalah sebagai keterampilan dan kebiasan yang telah mengkristal akibat pengalaman sebelumnya, seperti banyaknya menguasai kosa kata, pengetahuan, kebiasaan penalaran dan pelbagai hal yang berhubungan dengan semua yang akan meningkatkan intelegensi dimaksudkan.

Pemahaman mental kognitif dari teori Cattel di atas, membawa sebuah implikasi yang positif terhadap mengkristalnya mental kognitif dalam menyelesaikan masalah, disamping memberi pengaruh besar terhadap pengetahuan dan pengalaman keagamaan.

Dengan demikian Mental Kognitif Islam dapat dikatakan sebagai istilah khusus yang digunakan untuk melihat pola-pola dan cara berfikir seseorang individu tentang kualiti pengetahuan, pemahaman dan pengamalan tentang keislaman, atau dapat juga dikatakan mental kognitif Islam adalah cara berfikir umat Islam dalam memandang diri dan persekitarannya.

Oleh itu, dari definisi kognitif dan definisi mental yang di terokai, maka istilah Mental-Kognitif Islam defininya adalah suatu struktur dalaman manusia yang melahirkan persepsi, introspeksi, memori, kreativiti, imaginasi , konsepsi, keyakinan, penalaran, kemauan, dan emosi sebagai suatu kesatuan cara berfikir yang berteraskan Islam.

\section{Metode}

Kajian dijalankan secara tinjauan dengan menggunakan soal selidik sebagai instrumen kajian. Manakala persampelan kajian ini adalah berbentuk purposive random sampling, hal ini dimaksudkan sampel diambil hanya pada cluster umur remaja dan secara rawak diambil untuk dijadikan responden kajian. Responden seramai 490 orang remaja yang berumur dalam lingkungan 13 hingga 22 tahun yang berada dalam pusat pemulihan dan dari latar belakang demografi yang berbeza telah dipilih. Bagi responden kajian yang tidak pandai membaca, enumerator telah membantu membacakan soal selidik dimaksud tanpa menerangkan secara terperinci maksud soal selidik, kerana keterangan yang panjang dari enumerator akan menyebabkan tidak mendapat data sebenar tahap variabel mental-kognitif dan psikososial remaja yang akan diukur. Lokasi kajian ini diambil dari empat negeri iaitu Terengganu, Kelantan, Melaka dan Perak. Pemilihan lokasi ini berdasarkan keperluan untuk mengambil responden lelaki dan perempuan. Maka responden perempuan diambil pada pusat pemulihan Melaka, Terengganu dan Kelantan, manakala responden lelaki diambil pada pusat pemulihan di Perak dan Melaka.

Kajian ini menggunakan satu set soal selidik yang terbahagi kepada bahagian latar belakang responden dan bahagian skala-mental kognitif Islam (Khairil \& Khaidzir 2011).Tahap mental-kognitif Islam remaja diukur dengan menggunakan skala binari iaitu jawapan 'ya' dan 'tidak', dimana jawapan 'ya' diberi nilai 2 dan jawapan 'tidak' diberi nilai 1. Skala ini terdiri dari soalan 
Khairil Anwar, Indeks Mental - Kognitif Islam : Satu Penanda Aras Psikospirtual Islam Remaja Berisiko

positif dan negatif. Apabila soalan negatif dijawab pada pilihan 'ya' maka nilainya menjadi 1 dan sebaliknya bila memberi jawapan tidak akan diberi nilai 2. Skala ini memiliki 174 item terdiri dari 4 sub skala seperti di Jadual 3.5 memperlihatkan domain Tauhid 21 item, hukum Islam 79 item, pengetahuan Islam 51 item dan sejarah Islam 23 item.

Indeks mental-kognitif Islam julat yang tinggi adalah skor 60 ke atas. Manakala julat yang rendah adalah di bawah skor 60 ke bawah. Pilihan jawapan mempunyai dua julat (binary) ya dan tidak. Kenyataanpositif (seperti "keikhlasan dapat menyihatkan badan"). Bagi kenyataan negatif (seperti "tidak mengapa tidak percaya dengan adanya malaikat, yang penting percaya kepada Allah SWT")..

Data dianalisis menggunakan formula matematikal (Samsudin A. Rahim 2006) untuk mendapatkan skor domain mental kognitif Islam :

Skor Indikator : $\quad \sum\left[\underline{\mathrm{M}_{1}}-\underline{\mathrm{Ms}}\right] \times 100$

Skor domain : $\quad \bar{X}=\left[\sum\left[\underline{M_{1}}-\frac{M s}{R}\right] \times 100\right]$

Skor Indeks : $\quad \bar{X}$ indeks $=\frac{\sum \overline{\mathrm{X}} \text { domain }}{\mathrm{N} \text { domain }}$

Keterangan :

$\Sigma \quad$ : Jumlah skor Indeks

$M_{1} \quad:$ Min

$M_{s} \quad$ : skor minimum

$\mathrm{R} \quad$ : Range (skor maksimum tolak skor minimum)

100 : Skor tertinggi yang dianggarkan

\section{Hasil Penelitian}

\section{Domain Mental-Kognitif Islam}

Menerusi Jadual 1, menunjukkan Domain yang terdapat di dalam mental-kognitif Islam dan skor yang diperolehi. Skor-skor tersebut ialah tauhid (57.24), hukum Islam (57.71), Pengetahuan Islam (51.02) dan sejarah Islam (40.26). Indeks yang diperolehi untuk mental-kognitif Islam ialah 51.56. 
Al-Fikra: Jurnal IImiah Keislaman, Vol.14 , No.2 , Juli - Desember 2015

Jadual 1 Skor Domain Mental-Kognitif Islam

\begin{tabular}{lc}
\hline Domain Mental-Kognitif Islam & Skor \\
\hline Tauhid & 57.24 \\
Hukum Islam & 57.71 \\
Pengetahuan Islam & 51.02 \\
Sejarah Islam & 40.26 \\
Indeks Mental-Kognitif Islam & 51.56 \\
\hline
\end{tabular}

Rajah 1 memperlihatkan bahawa skor domain mental-kognitif Islam yang paling rendah dicapai adalah sejarah Islam (40.21). Selanjutnya Pengetahuan Islam dan tauhid. Manakala hukum Islam (57.71) menempati skor yang tertinggi.

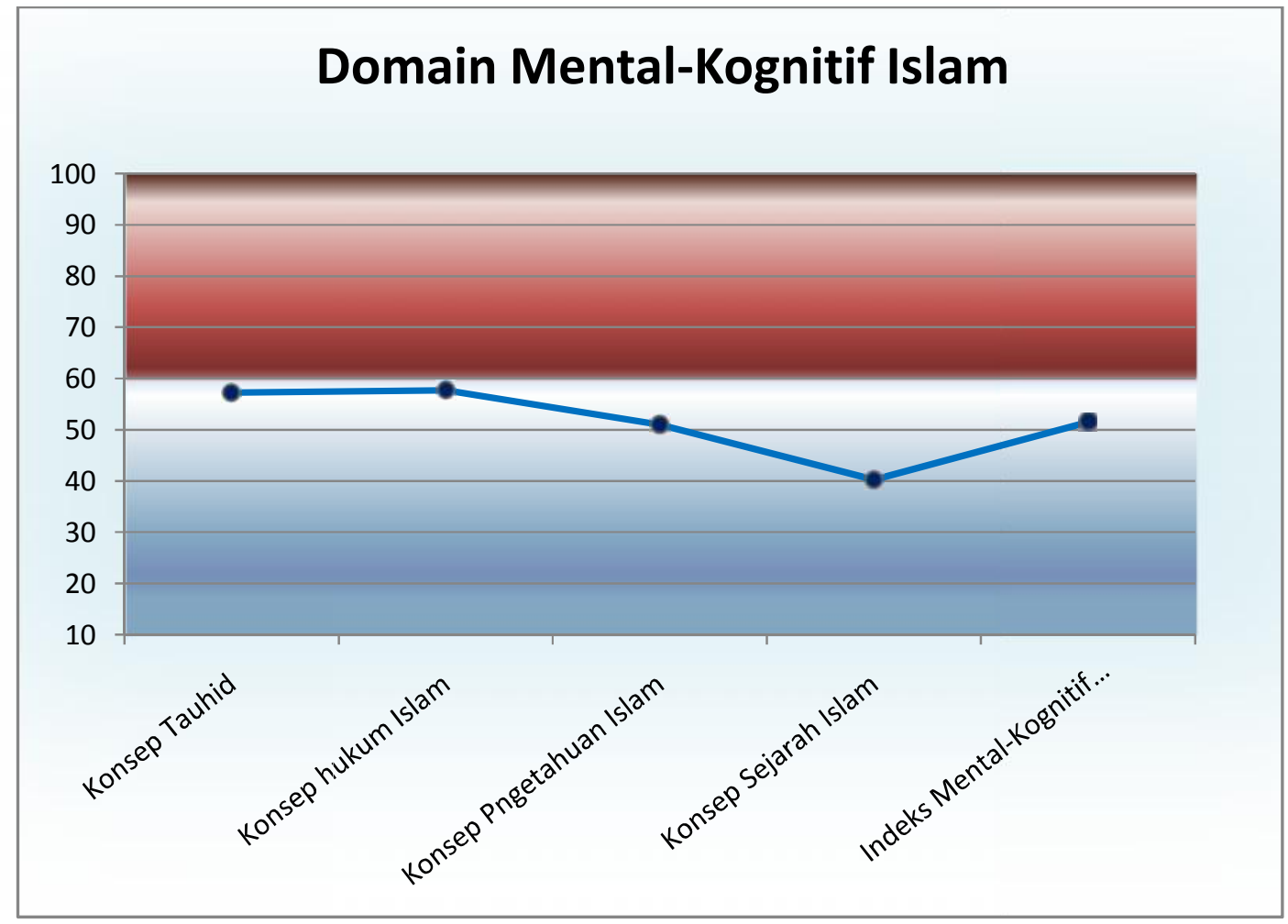

Rajah 1 Domain Mental-Kognitif Islam 
Khairil Anwar, Indeks Mental - Kognitif Islam : Satu Penanda Aras Psikospirtual Islam Remaja Berisiko

\begin{tabular}{|c|c|c|}
\hline Konstruk Mental-Kognitif & Islam Den & Skor Jantina \\
\hline \multirow[b]{2}{*}{ Konstruk Mental-Kognitif Islam } & \multicolumn{2}{|c|}{ Jantina } \\
\hline & Lelaki & Perempuan \\
\hline Tauhid & 55.67 & 59.10 \\
\hline Keadilan & 55.10 & 60.30 \\
\hline Musyawarah & 57.67 & 55.67 \\
\hline Jemaah & 51.20 & 48.80 \\
\hline Jenayah & 67.18 & 74.73 \\
\hline Sahsiah & 53.40 & 53.40 \\
\hline Muamalah & 65.22 & 68.22 \\
\hline Hukum Islam & 45.67 & 51.53 \\
\hline Pengetahuan Islam & 50.55 & 51.55 \\
\hline Ekonomi Islam & 47.22 & 51.78 \\
\hline Pengurusan Islam & 48.22 & 54.13 \\
\hline Keselamatan Dan Kesihatan Islam & 47.67 & 53.83 \\
\hline Sains Islam Islam & 52.83 & 54.75 \\
\hline Sejarah Islam & 42.52 & 37.30 \\
\hline
\end{tabular}

Jadual 3, menunjukkan Konstruk yang terdapat di dalam mental-kognitif Islam dan skor yang diperolehi berdasarkan jantina. Skor yang diperolehi bagi kumpulan lelaki dengan Konstruk tersebut ialah tauhid (55.67), keadilan (55.10), musyawarah (57.67), jemaah (51.20), Jenayah (67.18), sahsiah (53.40), muamalah (65.22), hukum Islam (45.67), Pengetahuan Islam(50.55), ekonomi Islam (47.22), pengurusan Islam (48.22),keselamatan dan kesihatan Islam (47.67), sains Islam (53.83) dan sejarah Islam (42.52).

Manakala skor yang diperolehi bagi kumpulan perempuan dengan konstruk tersebut ialah tauhid (59.10), keadilan (60.30), musyawarah (55.67), jemaah (48.80), jenayah (74.73), sahsiah (53.40), muamalah (68.22), hukum Islam (51.53), pengetahuan Islam(51.55), ekonomi Islam (51.78), pengurusan Islam (54.13), keselamatan dan kesihatan Islam (53.83), sains Islam (54.75) dan sejarah Islam (37.30). 


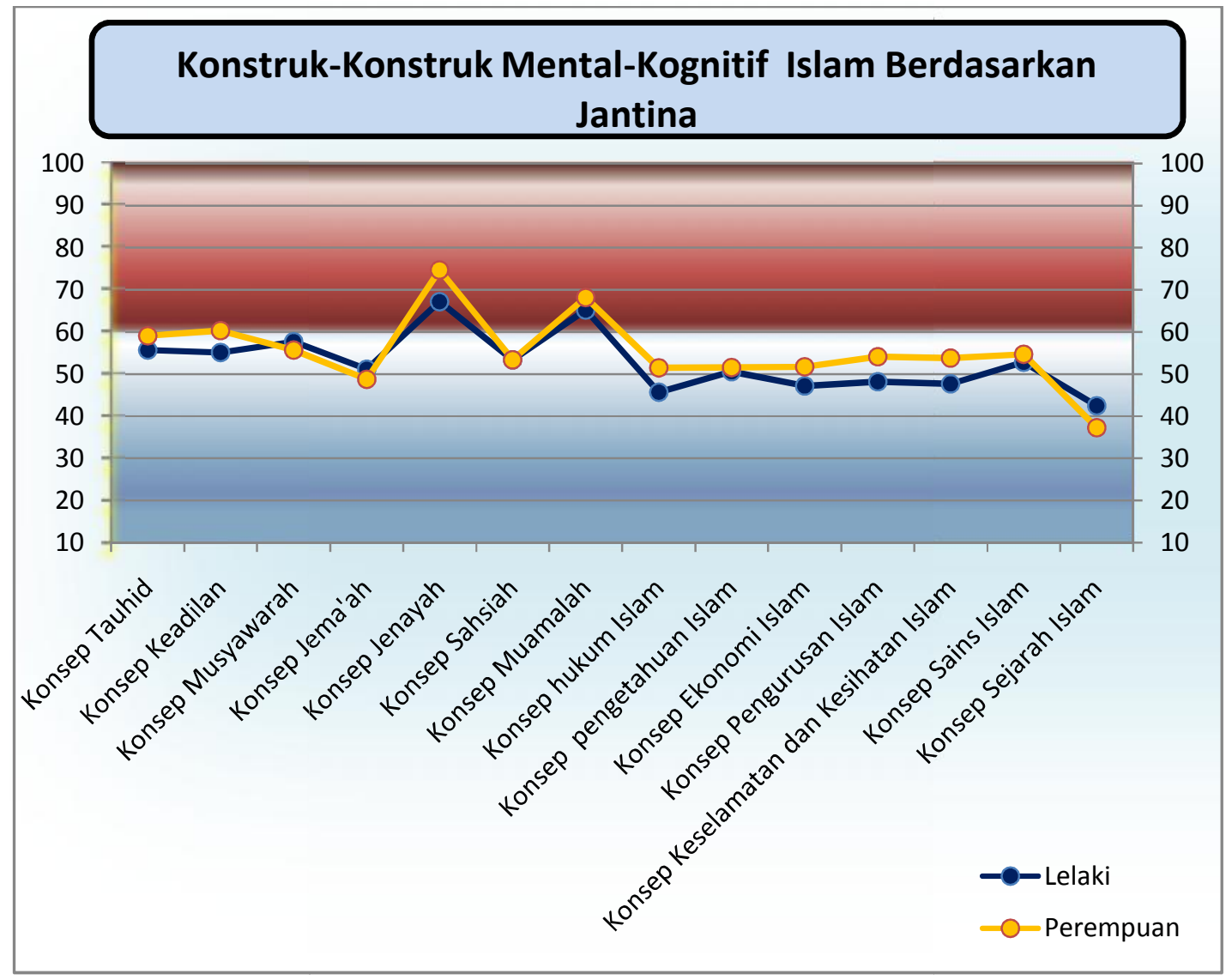

Rajah 3 Konstruk Mental-Kognitif Islam berdasarkan Jantina

Rajah 3 memperlihatkan bahawa responden lelaki dan perempuan samasama menempati skor terendah pada konstruk sejarah Islam. Pada konstruk ini skor perempuan (51.53) lebih tinggi berbanding lelaki (45.67). Demikian pula responden lelaki dan perempuan sama-sama menempati skor tertinggi pada konstruk konsep Jenayah. Pada konstruk ini skor perempuan (74.73) lebih tinggi berbanding lelaki (67.18). Secara umum skor perempuanlebih tinggi berbanding lelaki. 
Khairil Anwar, Indeks Mental - Kognitif Islam : Satu Penanda Aras Psikospirtual Islam Remaja Berisiko

\begin{tabular}{lcc}
\multirow{2}{*}{ Jadual 4} & Konstruk Mental-Kognitif Islam & \multicolumn{2}{c}{ Dengan Lokasi } \\
\cline { 2 - 3 } Konstruk Mental-Kognitif Islam & \multicolumn{2}{c}{ Lokasi } \\
\cline { 2 - 3 } Tauhid & Bandar & Bandar \\
\hline Keadilan & 57.81 & 56.71 \\
Musyawarah & 57.40 & 58.00 \\
Jemaah & 56.50 & 57.33 \\
Jenayah & 50.40 & 49.80 \\
Sahsiah & 72.53 & 68.93 \\
Muamalah & 54.80 & 51.60 \\
Hukum Islam & 66.89 & 66.56 \\
Pengetahuan Islam & 50.47 & 47.87 \\
Ekonomi Islam & 50.56 & 51.78 \\
Pengurusan Islam & 49.22 & 49.11 \\
Keselamatan Dan Kesihatan Islam & 52.53 & 48.33 \\
Sains Islam Islam & 51.67 & 48.33 \\
Sejarah Islam & 52.58 & 55.42 \\
& 40.47 & 39.97 \\
\hline
\end{tabular}

Berdasarkan jadual 4 menunjukkan konstruk yang terdapat di dalam mental-kognitif Islam dan skor yang diperolehi berdasarkan asal. skor yang diperolehi bagi responden yang berasal dari bandar dengan konstruk tersebut ialah tauhid (57.81), keadilan (57.40), musyawarah (56.50), jemaah (50.40) jenayah (72.53), sahsiah (54.80), muamalah (66.89), hukum Islam (50.47), pengetahuan Islam (50.56), ekonomi Islam (49.22), pengurusan Islam (52.53), keselamatan dan kesihatan Islam (51.67), sains Islam (52.58) dan sejarah Islam (40.47).

Manakala skor yang diperolehi bagi responden yang berasal dari luar bandar dengan konstruk tersebut ialah tauhid (56.71), keadilan (58.00), musyawarah (57.33), jemaah (49.80), jenayah (68.93), sahsiah (51.60), muamalah (66.56), hukum Islam (47.87), pengetahuan Islam (51.78), ekonomi Islam (49.11), pengurusan Islam (48.33), keselamatan dan kesihatan Islam (48.33), sains Islam (55.42) dan sejarah Islam (39.97). 


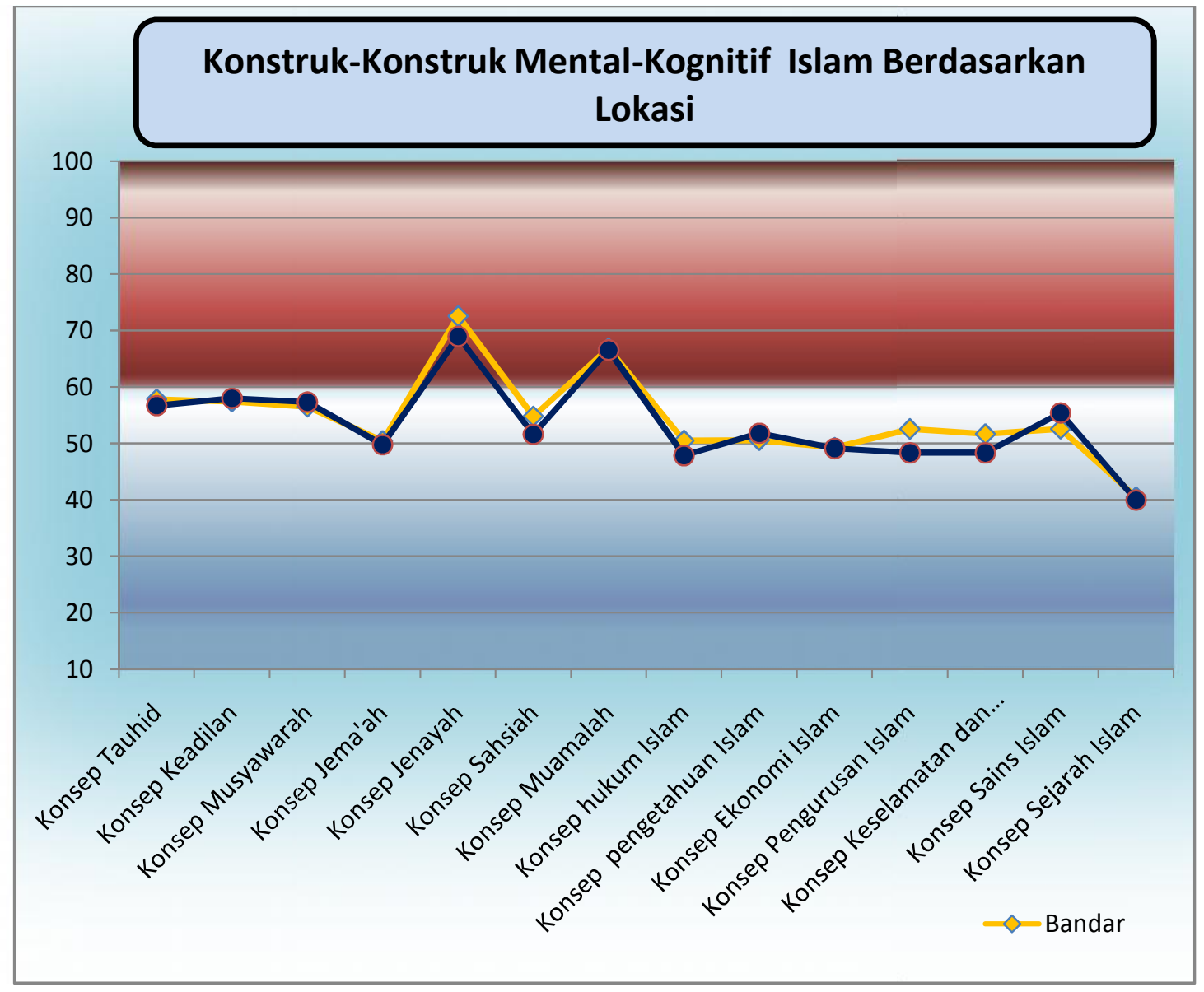

Rajah 4 Konstruk Mental-Kognitif Islam Berdasarkan Lokasi

Rajah 4 memperlihatkan bahawa responden asal bandar dan luar bandar sama-sama menempati skor terendah pada konstruk sejarah Islam. Pada konstruk ini skor asal bandar (40.47) lebih tinggi berbanding asal luar bandar (39.97). Demikian pula responden asal bandar dan luar bandar sama-sama menempati skor tertinggi pada konstruk konsep jenayah. Pada konstruk ini skor asal bandar (72.53) lebih tinggi berbanding asal luar bandar (68.93). secara umum skor Bandar dan luar Bandar adalah sama. 
Khairil Anwar, Indeks Mental - Kognitif Islam : Satu Penanda Aras Psikospirtual Islam Remaja Berisiko

Jadual 5 Konstruk Mental-Kognitif Islam Dengan Jenis Kesalahan

\begin{tabular}{|c|c|c|c|c|c|c|}
\hline \multirow[b]{2}{*}{$\begin{array}{l}\text { Konstruk } \\
\text { Mental-Kognitif Islam }\end{array}$} & \multicolumn{6}{|c|}{ Jenis kesalahan } \\
\hline & Seksual & Dadah & Mencuri & $\begin{array}{l}\text { Gengs } \\
\text { terisme }\end{array}$ & $\begin{array}{l}\text { Luar } \\
\text { kawalan }\end{array}$ & $\begin{array}{c}\text { Lari } \\
\text { dari } \\
\text { rumah }\end{array}$ \\
\hline Konsep tauhid & 58.04 & 57.00 & 57.00 & 55.47 & 61.47 & 58.05 \\
\hline Konsep keadilan & 60.50 & 59.40 & 55.60 & 55.00 & 58.90 & 59.30 \\
\hline Konsep musyawarah & 53.60 & 58.63 & 58.00 & 54.00 & 59.33 & 56.00 \\
\hline Konsep jemaah & 49.40 & 50.00 & 54.40 & 46.40 & 47.20 & 47.20 \\
\hline Konsep Jenayah & 66.67 & 73.33 & 68.93 & 67.80 & 66.73 & 69.53 \\
\hline Konsep sahsiah & 53.40 & 57.60 & 51.40 & 52.20 & 51.20 & 52.80 \\
\hline Konsep muamal & 59.89 & 70.33 & 64.11 & 65.89 & 69.56 & 68.00 \\
\hline $\begin{array}{l}\text { Konsep hukum Islam } \\
\text { Konsep pengetahuan }\end{array}$ & 50.93 & 49.73 & 49.60 & 45.20 & 51.60 & 50.80 \\
\hline Islam & 57.11 & 53.89 & 49.11 & 45.44 & 51.67 & 54.78 \\
\hline $\begin{array}{l}\text { Konsep ekonomi Islam } \\
\text { Konsep penqurusan }\end{array}$ & 50.67 & 49.78 & 49.33 & 45.67 & 51.56 & 50.67 \\
\hline $\begin{array}{l}\text { Islam } \\
\text { Konsep }\end{array}$ & 52.40 & 50.33 & 49.20 & 48.87 & 52.27 & 53.20 \\
\hline $\begin{array}{l}\text { keselamatan/kesihatan } \\
\text { Islam } \\
\text { Konsep sains Islam }\end{array}$ & 51.83 & 48.83 & 48.50 & 53.00 & 53.17 & 53.33 \\
\hline Islam & 54.67 & 54.83 & 51.83 & 51.67 & 55.67 & 55.25 \\
\hline Konsep sejarah Islam & 40.22 & 42.96 & 41.61 & 41.04 & 37.48 & 35.83 \\
\hline
\end{tabular}

Berdasarkan jadual 5 , menunjukkan konstruk yang terdapat di dalam mentalkognitif Islam dan skor yang diperolehi dengan jenis kesalahan. skor yang diperolehi bagi responden yang melakukan kesalahan seksual dengan konstruk tersebut ialah tauhid (58.04), keadilan (60.50), musyawarah (53.60), jemaah (49.40), jenayah (66.67), sahsiah (53.40), muamalah (59.89), hukum Islam (50.93), pengetahuan Islam (57.11), ekonomi Islam (50.67), pengurusan Islam (52.40), keselamatan dan kesihatan Islam (51.83), sains Islam (54.67) dan sejarah Islam (40.22).

Manakala skor yang diperolehi bagi responden yang melakukan kesalahan melibatkan dadah dengan konstruk tersebut ialah tauhid (57.00), keadilan (59.40), musyawarah (58.63), jemaah (50.00), jenayah (73.33), sahsiah (57.60), muamalah (70.33), hukum Islam (49.73), pengetahuan Islam (53.89), ekonomi Islam (49.78), pengurusan Islam (50.33), keselamatan dan kesihatan Islam (48.83), sains Islam (54.83) dan sejarah Islam (42.96). 
Bagi jenis kesalahan mencuri skor yang diperolehi dengan konstruk tersebut ialah tauhid (57.00), keadilan (55.60), musyawarah (58.00), jemaah (54.40), jenayah (68.93), sahsiah (51.40), muamalah (64.11), hukum Islam (49.60), pengetahuan Islam (49.11), ekonomi Islam (49.33), pengurusan Islam (49.20), keselamatan dan kesihatan Islam (48.50), sains Islam (51.83) dan sejarah Islam (41.61).

Skor yang diperolehi bagi responden yang melakukan kesalahan gangsterisme dengan konstruk tersebut ialah tauhid (55.47), keadilan (55.00), musyawarah (54.00), jemaah (46.40) jenayah (67.80), sahsiah (52.20), muamalah (65.89), hukum Islam (49.73), pengetahuan Islam (45.44), ekonomi Islam (45.67), pengurusan Islam (48.87), keselamatan dan kesihatan Islam (53.00), sains Islam (51.67) dan sejarah Islam (41.04).

Bagi jenis kesalahan luar kawalan skor yang diperolehi dengan konstruk tersebut ialah tauhid (61.47), keadilan (58.90), musyawarah (59.33), jemaah (47.20), jenayah (66.73), sahsiah (51.20), muamalah (69.56), hukum Islam(51.60), pengetahuan Islam (51.67), ekonomi Islam (51.56), pengurusan Islam (52.27), keselamatan dan kesihatan Islam (53.17), sains Islam (55.67) dan sejarah Islam (37.48).

Manakala skor yang diperolehi bagi responden yang melakukan kesalahan melibatkan dadah dengan konstruk tersebut ialah tauhid (57.00), keadilan (59.40), musyawarah (58.63), jemaah (50.00) jenayah (73.33), sahsiah (57.60), muamalah (70.33), hukum Islam (49.73), pengetahuan Islam (53.89), ekonomi Islam (49.78), pengurusan Islam (50.33), keselamatan dan kesihatan Islam (48.83), sains Islam (54.83) dan sejarah Islam (42.96).

Skor yang diperolehi bagi responden yang melakukan kesalahan lari dari rumah dengan konstruk tersebut ialah tauhid (58.05), keadilan (59.30), musyawarah (56.00), jemaah (47.20), jenayah (69.53), sahsiah (52.80), muamalah (68.00), hukum Islam (50.80), pengetahuan Islam (54.78), ekonomi Islam (50.67), pengurusan Islam (53.20), keselamatan dan kesihatan Islam (53.33), sains Islam (55.25) dan sejarah Islam (35.83). 
Khairil Anwar, Indeks Mental - Kognitif Islam : Satu Penanda Aras Psikospirtual Islam Remaja Berisiko

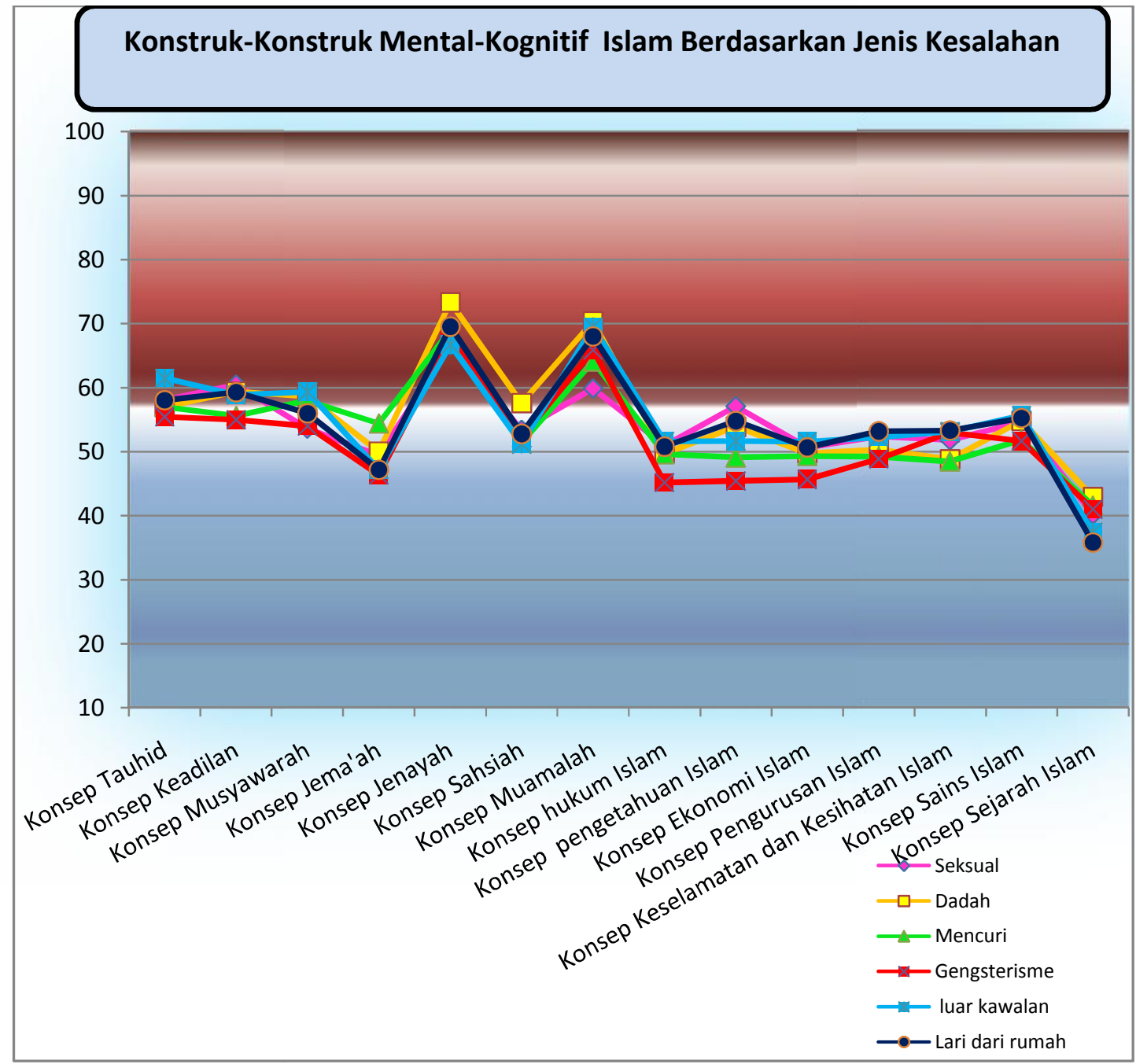

Rajah 5 Konstruk Mental-Kognitif Berdasarkan Jenis Kesalahan

Rajah 5 memperlihatkan bahawa responden mengikut jenis kesalahan adalah sama-sama menempati skor terendah pada konstruk sejarah Islam. Pada konstruk ini skor terendah terdapat pada jenis kesalahan lari dari rumah (35.83).. Demikian pula responden mengikut jenis kesalahan juga samasama menempati skor tertinggi pada konstruk konsep Jenayah. Pada konstruk ini skor jenis kesalahan dadah (73.33) menempati paling tinggi. Secara umum skor terendah adalah pada jenis kesalahan gangsterisma. 
Jadual 6 Konstruk Mental-Kognitif Islam Dengan Pendapatan

\begin{tabular}{|c|c|c|c|c|c|c|}
\hline \multirow{2}{*}{$\begin{array}{l}\text { Konstruk } \\
\text { Mental-Kognitif Islam }\end{array}$} & \multicolumn{6}{|c|}{ Pendapatan } \\
\hline & 1 & 2 & 3 & 4 & 5 & 6 \\
\hline Konsep tauhid & 51.95 & 58.29 & 56.05 & 67.95 & 65.00 & 60.52 \\
\hline Konsep keadilan & 50.00 & 57.00 & 56.60 & 67.70 & 64.50 & 56.40 \\
\hline Konsep musyawarah & 51.50 & 61.67 & 56.00 & 63.50 & 56.67 & 48.83 \\
\hline Konsep jemaah & 46.40 & 53.40 & 48.20 & 50.00 & 54.0 & 61.40 \\
\hline Konsep Jenayah & 64.93 & 70.60 & 70.8 & 78.46 & 79.33 & 74.73 \\
\hline Konsep sahsiah & 52.40 & 56.40 & 55.20 & 53.60 & 53.00 & 50.00 \\
\hline Konsep muamalah & 63.78 & 68.22 & 68.22 & 75.78 & 70.00 & 69.89 \\
\hline Konsep hukum Islam & 46.27 & 49.47 & 48.27 & 60.93 & 51.33 & 57.13 \\
\hline Konsep pengetahuan Islam & 45.78 & 54.67 & 53.33 & 57.11 & 57.78 & 52.33 \\
\hline Konsep ekonomi Islam & 42.78 & 52.56 & 51.33 & 56.11 & 49.44 & 49.22 \\
\hline $\begin{array}{l}\text { Konsep pengurusan Islam } \\
\text { Konsep keselamatan/ }\end{array}$ & 48.27 & 52.33 & 50.73 & 52.40 & 54.00 & 55.27 \\
\hline kesihatan Islam & 40.83 & 50.50 & 49.00 & 53.83 & 63.33 & 61.83 \\
\hline Konsep sains Islam Islam & 48.75 & 51.33 & 54.33 & 64.67 & 55 & 49.42 \\
\hline Konsep sejarah Islam & 40.96 & 37.70 & 40.96 & 36.57 & 41.96 & 43.17 \\
\hline
\end{tabular}

Keterangan : (1). RM 200-550, (2).RM 600-950, (3).RM 1000-2000, (4).RM. 2100-3000, (5).RM 3100-5000, (6).RM 6000 ke atas

Menerusi jadual 6, menunjukkan konstruk yang terdapat di dalam mental-kognitif Islam dan skor yang diperolehi dengan pendapatan keluarga. skor yang diperolehi bagi responden yang mempunyai pendapatan sebanyak RM 200-RM 550 dengan konstruk tersebut ialah tauhid (51.95), keadilan (50), musyawarah (51.5), jemaah (46.4), jenayah (64.93), sahsiah (52.4), muamalah (63.78), hukum Islam (46.27), pengetahuan Islam(45.78), ekonomi Islam (42.78), pengurusan Islam (48.27), keselamatan dan kesihatan Islam (40.83), sains Islam (48.75) dan sejarah Islam (40.96).

Manakala skor yang diperolehi bagi responden yang mempunyai pendapatan RM 600 -950 dengan konstruk tersebut ialah tauhid (58.29), keadilan (57), musyawarah (61.67), jemaah (53.4) jenayah (70.6), sahsiah (56.4), muamalah (68.22), hukum Islam (49.47), pengetahuan Islam(54.67), ekonomi Islam (52.56), pengurusan Islam (52.33), keselamatan dan kesihatan Islam (50.5), sains Islam (51.33) dan sejarah Islam (37.7).

Bagi pendapatan RM 1000 - RM 2000 skor yang diperolehi dengan konstruk tersebut ialah tauhid (56.05), keadilan (56.6), musyawarah (56), jemaah (48.2) jenayah (70.8), sahsiah (55.2), muamalah (68.22), hukum Islam (48.27), pengetahuan Islam (53.33), ekonomi Islam (51.33), 
Khairil Anwar, Indeks Mental - Kognitif Islam : Satu Penanda Aras Psikospirtual Islam Remaja Berisiko

pengurusan Islam (50.73), keselamatan dan kesihatan Islam (49), sains Islam (54.33) dan sejarah Islam (40.96).

Skor yang diperolehi bagi responden yang mempunyai pendapatan RM 2100 - RM 3000 dengan konstruk tersebut ialah tauhid (67.95), keadilan (67.7), musyawarah (63.5), jemaah (50), jenayah (78.46), sahsiah (53.6), muamalah (75.78), hukum Islam (60.93), pengetahuan Islam(57.11), ekonomi Islam (56.11), pengurusan Islam (52.4), keselamatan dan kesihatan Islam (53.83), sains Islam (64.67) dan sejarah Islam (36.57).

Bagi pendapatan RM 3100 - RM 5000 skor yang diperolehi dengan konstruk tersebut ialah tauhid (65), keadilan (64.5), musyawarah (56.67), jemaah (54), jenayah (79.33), sahsiah (53), muamalah (70), hukum Islam (51.33), pengetahuan Islam (57.78), ekonomi Islam (49.44), pengurusan Islam (54), keselamatan dan kesihatan Islam (63.33), sains Islam (55) dan sejarah Islam (41.96).

Manakala skor yang diperolehi bagi responden yang berpendapatan RM 6000 ke atas dengan konstruk tersebut ialah tauhid (60.52), keadilan (56.4), musyawarah (48.83), jemaah (61.4), jenayah (74.73), sahsiah (50), muamalah (69.89), hukum Islam (57.13), pengetahuan Islam(52.33), ekonomi Islam (49.22), pengurusan Islam (55.27), keselamatan dan kesihatan Islam (61.83), sains Islam (49.42) dan sejarah Islam (43.17). 


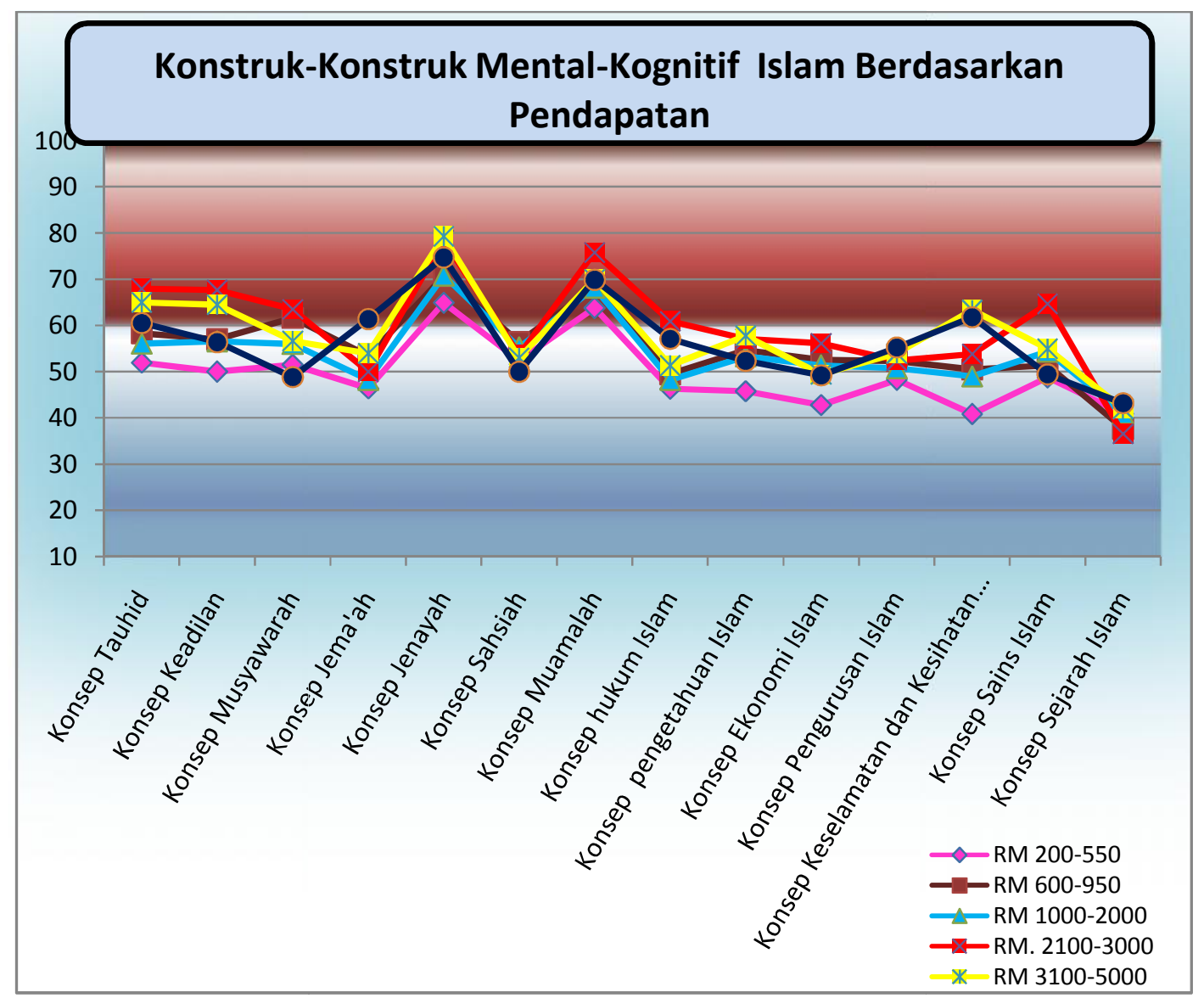

Rajah 6 Konstruk Mental-Kognitif Islam Berdasarkan Pendapatan

Rajah 6 memperlihatkan bahawa responden dengan pendapatan keluarga RM. 200-550 (40.83) skor yang terendah adalah pada konstruk keselamatan dan kesihatan. Manakala Responden selain berpendapatan RM. 200-550 menempati skor terendah pada kosep sejarah Islam. Mengikut tahap pendapatan ini secara keseluruhan, menempati skor yang tertinggi pada Konsep Jenayah. Secara umum skor setiap konstruk yang terendah adalah terdapat pada kumpulan pendapatan RM. 200-550. 
Khairil Anwar, Indeks Mental - Kognitif Islam : Satu Penanda Aras Psikospirtual Islam Remaja Berisiko

Jadual 7 Konstruk Mental-Kognitif Islam Dengan Tahap Umur

\begin{tabular}{lccc}
\hline & \multicolumn{3}{c}{ Tahap umur } \\
\cline { 2 - 4 } Konstruk & $\begin{array}{c}\text { 13-15 tahun } \\
\text { (Remaja } \\
\text { awal) }\end{array}$ & $\begin{array}{c}\text { 16-18 tahun } \\
\text { (Remaja } \\
\text { pertengahan) }\end{array}$ & $\begin{array}{c}19-22 \\
\text { tahun } \\
\text { (Remaja } \\
\text { akhir) }\end{array}$ \\
\hline Konsep tauhid & 50.43 & 57.95 & 57.71 \\
Konsep keadilan & 45.70 & 58.60 & 58.80 \\
Konsep musyawarah & 45.67 & 56.50 & 59.50 \\
Konsep jemaah & 43.00 & 50.60 & 51.00 \\
Konsep Jenayah & 59.73 & 72.20 & 71.60 \\
Konsep sahsiah & 45.20 & 55.00 & 53.20 \\
Konsep muamalah & 57.44 & 67.67 & 67.67 \\
Konsep hukum Islam & 40.00 & 49.73 & 51.00 \\
Konsep pengetahuan Islam & 40.00 & 51.22 & 53.22 \\
Konsep ekonomi Islam & 43.00 & 50.22 & 49.67 \\
Konsep pengurusan Islam & 43.53 & 52.07 & 50.53 \\
Konsep keselamatan / & & & \\
kesihatan Islam & 45.00 & 50.33 & 50.67 \\
Konsep sains Islam Islam & 45.33 & 54.67 & 54.00 \\
Konsep sejarah Islam & 35.61 & 39.96 & 41.52 \\
\hline
\end{tabular}

Berdasarkan jadual 7 , menunjukkan konstruk yang terdapat di dalam mental-kognitif Islam dan skor yang diperolehi dengan tahap umur. skor yang diperolehi bagi responden yang berumur $13-15$ tahun (remaja awal) dengan konstruk tersebut ialah tauhid (50.43), keadilan (45.70), musyawarah (45.67), jemaah (43.00), jenayah (59.73), sahsiah (45.20), muamalah (57.44), hukum Islam (40.00), pengetahuan Islam(40.00), ekonomi Islam (43.00), pengurusan Islam (43.53), keselamatan dan kesihatan Islam (45.00), sains Islam (45.33) dan sejarah Islam (35.61).

Manakala skor yang diperolehi bagi responden yang berumur $16-18$ tahun (remaja pertengahan) dengan konstruk tersebut ialah tauhid (57.95), keadilan (58.60), musyawarah (56.50), jemaah (50.60) jenayah (72.20), sahsiah (55.00), muamalah (67.67), hukum Islam (49.73), pengetahuan Islam(51.22), ekonomi Islam (50.22), pengurusan Islam (52.07), keselamatan dan kesihatan Islam (50.33), sains Islam (54.67) dan sejarah Islam (39.96).

Bagi responden yang berumur $19-22$ tahun (remaja akhir) skor yang diperolehi dengan konstruk tersebut ialah tauhid (57.71), keadilan (58.80), musyawarah (59.50), jemaah (51.00) jenayah (71.60), sahsiah (53.20), 
Al-Fikra: Jurnal IImiah Keislaman, Vol.14, No.2, Juli - Desember 2015

muamalah (67.67), hukum Islam (51.00), pengetahuan Islam(53.22), ekonomi Islam (49.67), pengurusan Islam (50.53), keselamatan dan kesihatan Islam (50.67), sains Islam (54.00) dan sejarah Islam (41.52).

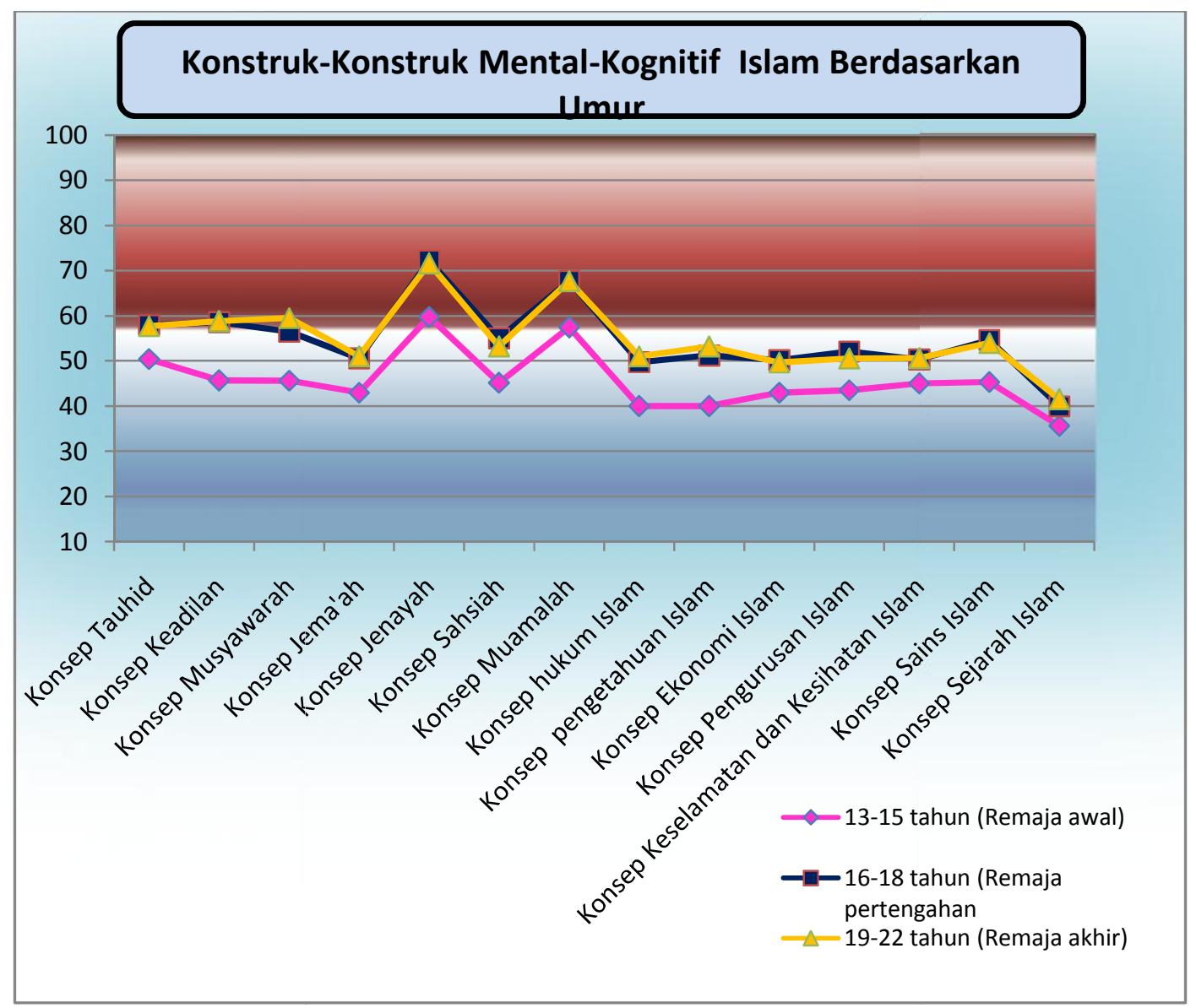

Rajah 7 Konstruk Mental-Kognitif Islam Berdasarkan Umur

Rajah 7 memperlihatkan bahawa responden mengikut umur adalah samasama menempati skor terendah pada konstruk sejarah Islam. Pada konstruk ini skor terendah terdapat pada tahap umur 13-15 tahun (35.61).. Demikian pula responden mengikut umur juga sama-sama menempati skor tertinggi pada konstruk konsep Jenayah. Pada konstruk ini skor tahap umur 16-18 tahun (72.20) menempati paling tinggi. Secara umum skor terendah pada konstruk Mental-kognitif Islam adalah dalam kumpulan umur 13-15 tahun sebagai yang disebut remaja awal. 
Khairil Anwar, Indeks Mental - Kognitif Islam : Satu Penanda Aras Psikospirtual Islam Remaja Berisiko

Jadual 8 Konstruk Mental-Kognitif Islam dengan Tahap Sekolah Responden

\begin{tabular}{lccc}
\hline & \multicolumn{3}{c}{ Tahap Sekolah } \\
\cline { 2 - 4 } Konstruk & $\begin{array}{c}\text { Sekolah } \\
\text { rendah/ } \\
\text { tidak } \\
\text { sekolah }\end{array}$ & $\begin{array}{c}\text { Sekolah } \\
\text { menengah }\end{array}$ & $\begin{array}{c}\text { Sekolah } \\
\text { kemahiran }\end{array}$ \\
\hline Konsep tauhid & 44.62 & 60.05 & 58.81 \\
Konsep keadilan & 47.30 & 59.40 & 60.00 \\
Konsep musyawarah & 49.67 & 59.33 & 57.00 \\
Konsep jemaah & 45.80 & 51.00 & 52.80 \\
Konsep Jenayah & 62.07 & 73.33 & 73.47 \\
Konsep sahsiah & 52.40 & 54.60 & 52.00 \\
Konsep muamalah & 59.78 & 69.22 & 66.22 \\
Konsep hukum Islam & 41.53 & 51.53 & 52.13 \\
Konsep pengetahuan Islam & 43.22 & 54.11 & 51.56 \\
Konsep ekonomi Islam & 40.44 & 50.89 & 48.44 \\
Konsep pengurusan Islam & 40.73 & 52.20 & 53.47 \\
Konsep keselamatan/kesihatan & & & \\
Islam & 40.17 & 53.00 & 46.00 \\
Konsep sains Islam Islam & 43.83 & 56.83 & 52.75 \\
Konsep sejarah Islam & 35.78 & 40.78 & 46.09 \\
\hline
\end{tabular}

Menerusi jadual 8, menunjukkan konstruk yang terdapat di dalam mental-kognitif Islam dan skor yang diperolehi dengan tahap pendidikan. skor yang diperolehi responden yang tahap pendidikan sehingga sekolah rendah/tidak bersekolah dengan konstruk tersebut ialah tauhid (44.62), keadilan (47.30), musyawarah (49.67), jemaah (45.80) jenayah (62.07), sahsiah (52.40), muamalah (59.78), hukum Islam (41.53), pengetahuan Islam (43.22), ekonomi Islam (40.44), pengurusan Islam (40.73), keselamatan dan kesihatan Islam (40.17), sains Islam (43.83) dan sejarah Islam (35.78).

Manakala skor yang diperolehi responden yang tahap pendidikan sehingga sekolah menengah dengan konstruk tersebut ialah tauhid (60.05), keadilan (59.40), musyawarah (59.33), jemaah (51.00), jenayah (73.33), sahsiah (54.60), muamalah (69.22), hukum Islam (51.53), pengetahuan Islam(54.11), ekonomi Islam (50.89), pengurusan Islam (52.20), keselamatan dan kesihatan Islam (53.00), sains Islam (56.83) dan sejarah Islam (40.78).

Bagi responden yang tahap pedidikan sehingga sekolah kemahiran skor yang diperolehi dengan konstruk tersebut ialah tauhid (58.81), keadilan (60.00), musyawarah (57.00), jemaah (52.80) jenayah (73.47), sahsiah 
Al-Fikra: Jurnal IImiah Keislaman, Vol.14, No.2, Juli - Desember 2015

(52.00), muamalah (66.22), hukum Islam (52.13), pengetahuan Islam (51.56), ekonomi Islam (48.44), pengurusan Islam (53.47), keselamatan dan kesihatan Islam (46.00), sains Islam (52.75) dan sejarah Islam (46.09).

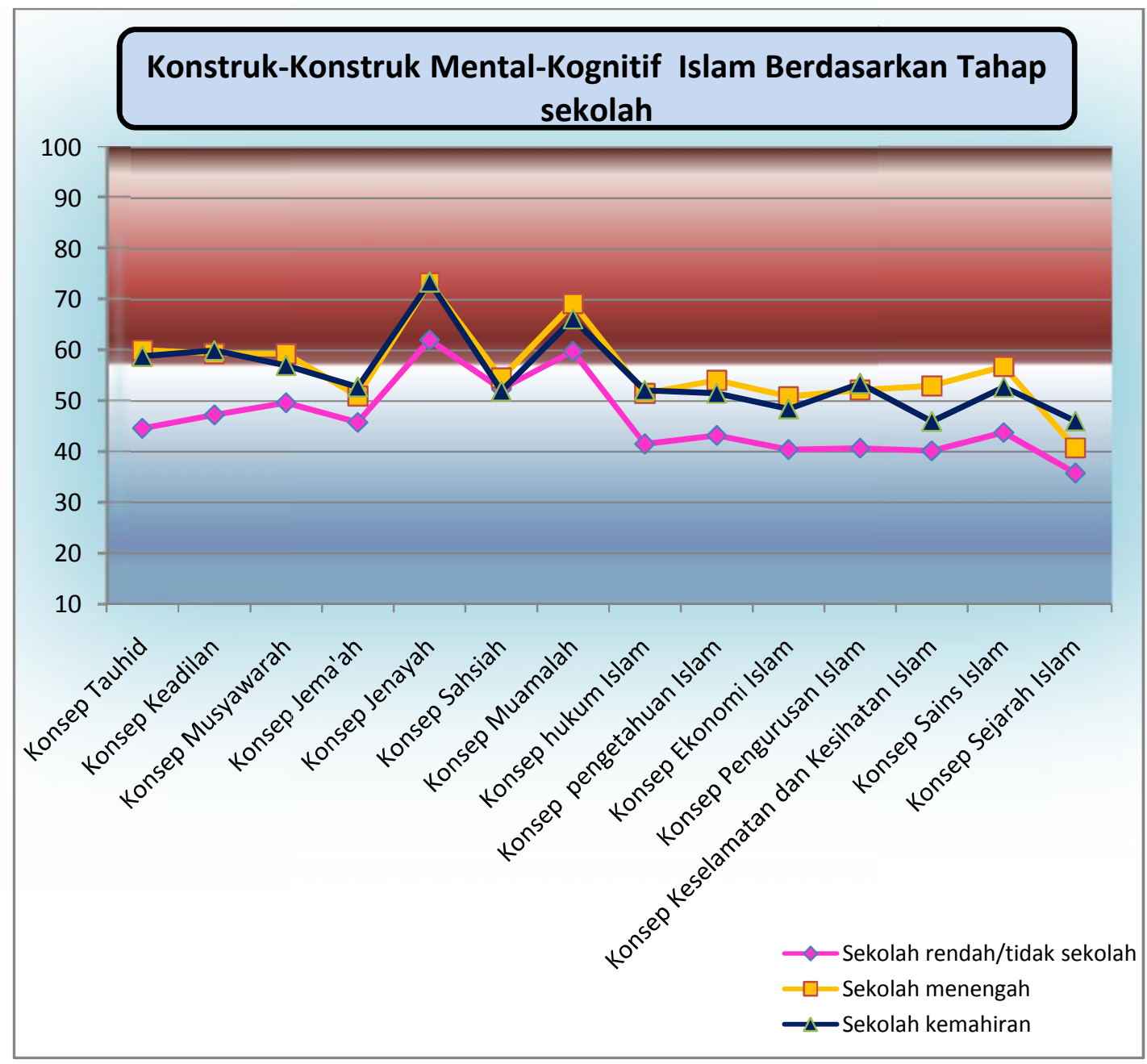

Rajah 8 Konstruk Mental-Kognitif Islam Berdasarkan Tahap Sekolah Rajah 8 memperlihatkan bahawa responden mengikut tahap sekolah adalah sama-sama menempati skor terendah pada konstruk sejarah Islam. Pada konstruk ini skor terendah terdapat pada tahap sekolah rendah/tidak bersekolah (35.78).. Demikian pula responden mengikut tahap sekolah juga sama-sama menempati skor tertinggi pada konstruk konsep Jenayah. Pada konstruk ini skor tahap sekolah kemahiran (73.47) menempati paling tinggi. Secara umum skor konstruk mental-kognitif Islam yang paling rendah adalah 
Khairil Anwar, Indeks Mental - Kognitif Islam : Satu Penanda Aras Psikospirtual Islam Remaja Berisiko

dalam kumpulan tahap sekolah rendah/tidak bersekolah. Dan yang paling tinggi adalah pada kumpulan sekolah menengah.

\section{Pembahasan}

Secara umum profil mental kognitif islam diukur dengan skor di bawah 60 adalah aras rendah dan 60 ke atas adalah aras tinggi. Kajian ini remaja berisiko berada pada paras skor yang rendah (51.56). Mental-kognitif yang menggambarkan cara berfikir bathiniyyah (mental) remaja adalah suatu konsep penting yang akan menetukan sikap dan tingkahlaku remaja dalam persekitaran yang penuh dengan pelbagai gejala sosial. Mental kognitif islam yang jauh adalah suatu aspek yag merupakan cara pandang kehidupan seorang muslim dari sudut agama yang diyakini secara mendalam dan lebih cenderung lebih mengutamakan dalaman daripada simbol luaran. Indikatorindikator yang terdapat dalam pengukuran mental-kognitif Islam ini dibina secara khas untuk melakukan penilaian. Rendahnya aras mental kognitif islam remaja adalah salah satu yang boleh dijadikan indikator mengapa terjadinya tingkahlaku anti sosial dalam kalangan remaja.

Pengukuran Mental kognitif ini dibina bertujuan untuk menggambarkan pemikiran dan amalan keagamaan yang bersifat abstrak bukan yang kongkrit. Salah satu contoh item " boleh berpelukan dan bercumbu asal tidak berzina". Item ini adalah bersifat abstrak untuk mengukur kecendrungan tingkahlaku zina, dan bukan mengukur hukum berzina. Bagi seseorang yang befikiran kongkrit akan menjawab ya, kerana mereka akan terpengaruh dengan hukum perilaku berzina. Namun bagi mereka yang berfikiran abstrak mereka akan menjawab tidak, kerana mereka akan mendahulukan kejadian dan hukum sesuatu perkara bergantung pada sebab dan akibat (kausaliti). Kebanyakan remaja berisiko dalam kajian ini menjawab ya. Seperti item " boleh menjual arak kepada orang bukan Islam", kebanyakan remaja dalam kajian ini menjawab ya. Jawapan ini menunjukkan betapa rendahnya mental kognitif remaja dalam menilai hukum halalnya suatu perbuatan. Mereka lebih mendahulukan hukum haram meminum arak, dan mereka abaikan hukum menjualnya. Dalam tradisi pendidikan pengajaran Islam, kurikulum pendidikan Islam hanya mengajar tentang hukum halal sesuatu perbuatan ataupun zat, namun dari segi perbuatan lainnya diabaikan. Seperti yang kita ketahui, hukum meminum arak dan menjual arak untuk orang muslim adalah haram. Namun menjual arak untuk orang yang bukan muslim tidak mendapat penjelasan yang baik. Seakan-akan zat haram hanya dilarang untuk orang Islam, padahal hukum yang ditetapkan Allah adalah untuk semua manusia. Setiap orang islam wajib melarang orang lain melakukan perbuatan haram, dan hasil penjualan zat haram hukumnya adalah haram serta membantu menyediakan benda haram hukumnya adalah haram. Pemahaman holistik ini 
Al-Fikra: Jurnal IImiah Keislaman, Vol.14, No.2, Juli - Desember 2015

membawa impak sosial yang luas untuk mencegah berlakunya gejala sosial, khususnya gejala sosial dalam kalangan remaja Islam.

Rendahnya aras mental kognitif remaja Islam membawa makna yang sangat signifikan tentang pemahaman islam yang syumul dalam kalangan remaja berada dalam keadaan kritikal. Aktiviti jenayah akan terus berlaku dalam kalangan remaja, selagi aras mental kognitif islam tidak ditingkatkan secepat mungkin.

Keyakinan sebagai salah satu asas penting mental kognitif Islam untuk memperbaiki sikap dan tingkahlaku manusia, khususnya bagi para remaja. Keyakinan ini dapat mematahkan pertumbuhan pemikiran yang materialisma dalam kalangan remaja, dan menyuburkan semangat bekerja dan berusaha. Allah SWT mewajibkan kita berusaha namun menjatuhkan hukum haram meyakini apa yang diusahakan merupakan pemikiran yang bagus. Pola berfikir ini adalah bentuk kesejahteraan psikologi yang berlandaskan Islam. Tauhid sebagai asas utama Psikologi Islam tidak jumud, namun ia dapat mencerdaskan akal manusia agar tidak dibelenggu oleh pemikiran materilispositivisma, sebagai pemacu tingkahlaku yang cenderung ke arah anti sosial.

Ketauhidan yang benar dan lurus akan menerangi kehidupan masyarakat dengan pancaran cahayanya, sekaligus memberi pengaruh luar biasa terhadap dimensi kehidupan sama ada dalam pemikiran, pemahaman, perasaan, akhlak mahupun aturan. Keimanan adalah proses kejiwaan yang berkaitan dengan dimensi rohani, meliputi akal, keinginan dan perasaan manusia. (Yusuf, Muhammad al-Sayyid dan Durrah, Ahmad. 2008) Qardawi (2007) mengatakan jika dikaitkan dengan individu dan masyarakat, iman merupakan benteng yang mampu menjaganya dari kebinasaan dan pelbagai marabahaya. Kehidupan yang terlepas daripada iman adalah kehidupan yang tidak mengandung kebajikan, kemuliaan dan peri kemanusiaan. Unsur keburukan, kerosakan, dan marabahaya akan subur di dalam jiwa. Individu atau masyarakat yang hidup tanpa iman dan agama bagaikan anai-anai yang ditiup angin; sangat rapuh, lemah, hilang tujuan hidup, terasing, mudah terombang ambing kesana kemari, sentiasa berasa tidak tenang, tidak memiliki halatuju hidup yang jelas, sentiasa berasa bimbang, serta tidak memahami hakikat diri dan rahsia dirinya diciptakan. 
Khairil Anwar, Indeks Mental - Kognitif Islam : Satu Penanda Aras Psikospirtual Islam Remaja Berisiko

\section{DAFTAR PUSTAKA}

Cattell, R.B. 1963. Theory of fluid and crystallized intelligence: A critical experiment. J ournal of Educational P sychology 54, 1-22.

Fuad Amsyari. 1995. Islam Kaaffah: tantangan sosial dan aplikasinya di Indonesia. Jakarta: Gema Insani press.

Halstead, B. 1992. Young people as victims of violence. Tasmania: National clearinghouse for youth studies.

Hamzah Ya'qub. 1983. Etika islam pembinaan akhlakul karimah. Bandung: CV. Diponegoro.

Khaidzir Hj. Ismail \& Khairil Anwar. 2011. Psikologi Islam : Suatu Pendekatan Psikometrik Remaja Berisiko (Islamic Psychology: An Approach To Psychometric For At-Risk Adolescence). J urnal E-Bangi 6(1): 77-89.

Khaidzir Hj. Ismail. 2007. Profile of At-Risk Female Adolescent: A Case Study in Selangor. INMIND, National.

Saifuddin Azwar. 1996. Psikologi Intelegensi. Yogyakarta : Pustaka Belajar.

Samsudin A. Rahim et al. 2006. Indeks Belia Malaysia. Putra Jaya: Institut Penyelidikan Pembangunan Belia Malaysia (IPPBM).

Yahya, harun. 2002. Moralitas AI-Qur'an; S olusi Atas Segala Persoalan Umat Manusia. Jakarta; Rabbani Press.

Yusuf, al-Sayyid, Muhammad \& Durrah, Ahmad. 2008. Pustaka Pengetahuan al-Qur'an: IImu Pengetahuan. Volume ke-6. Jakarta: PT. Rehal Republika. 